NASA Technical Memorandum 100793

\title{
Mechanics of Composite Materials: Past, Present, and Future
}

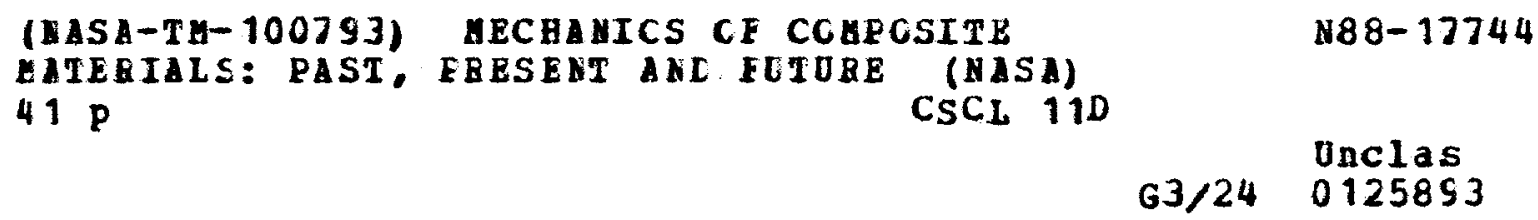

Christos C. Chamis

Lewis Research Center

Cleveland, Ohio

Presented at the 21st Annual Meeting of the Society for Engineering Science Blacksburg, Virginia, October 15-17, 1984 
MECHANICS OF COMPOSITE MATERIALS: PAST, PRESENT, AND FUTURE

Christos C. Chamis

\author{
National Aeronautics and Space Administration \\ Lewis Research Center \\ Cleveland, Ohio 44135
}

\begin{abstract}
Composite mechanics disciplines are presented and described at their various levels of sophistication and attendant scales of application. Correlation with experimental data is used as the prime discriminator between alternative methods and level of sophistication. Major emphas is is placed on: (1) where composite mechanics has been; (2) what it has accomplished; (3) where it is headed, based on present research activities; and (4) at the risk of being presumptuous, where it should be headed. The discussion is developed using selected, but typical, examples of each composite mechanics discipline identifying degree of success, with respect to correlation with experimental data, and problems remaining. The discussion is centered about fiber/resin composites drawn mainly from the author's research activities/experience spanning two decades at Lewis.
\end{abstract}

STAR CATEGORY 24

Key words: Fiber-composites; Resin-matrices; Interply hybrids; Intraply hybrids; Micromechanics; Macromechanics; Combined-stress failure; Laminate theory; Singularity mechanics; Life/durability; Fracture toughness; Damage tolerance; Progressive fracture; Structural analysis; Environmental effects 


\section{INTRODUCTION/BACKGROUND}

Composite mechanics has evolved to encompass a wide range of continuum and discrete mechanics methods. These methods are used to study and predict fiber/matrix composite behavior. The composite behavior is studied and/or predicted at various inherent scales (corresponding to the fabrication processes) in the composite from microstructure to structural response. Within each inherent scale has evolved a specialty composites mechanics discipline with several levels of sophistication.

The various levels of sophistication that have evolved in each composite mechanics discipline were influenced by three important factors: capturing the intrinsic physics; (2) degree of local detail desired; and (3) technical interests of the investigator(s). Collectively, these three factors have led to numerous significant contributions at the various scales of composite behavior.

The objective of this report is to describe/discuss composite mechanics at its various levels of sophistication and attendant inherent scales of application with respect to past, present, and future. The intent of preparing such a report is to stimulate thinking which will hopefully lead to "revolutionary" research. The description/discussion is organized as follows: (1) composite mechanics inherent scales; (2) composite mechanics disciplines; (3) composite mechanics discipline levels of sophistication; (4) factors influencing composite mechanics discipline; scale, and level of sophistication; (5) discriminators between alternate methods of level of sophistication; (6) composite mechanics - where it has been; (7) composite mechanics - what it has accomplished; (8) composite mechanics - where it is headed; and (9) composite mechanics - where it should go (a personal view). 
Examples are used to supplement and complement the discussion. These examples are mainly taken from the author and his Lewis collegues' research over the years. However, they are representative of the evolution of composite mechanics during that period. The references sited are NASA reports which are available in practically all technical libraries. Each of these references includes relevant references for that subject.

\section{SYMBOLS}

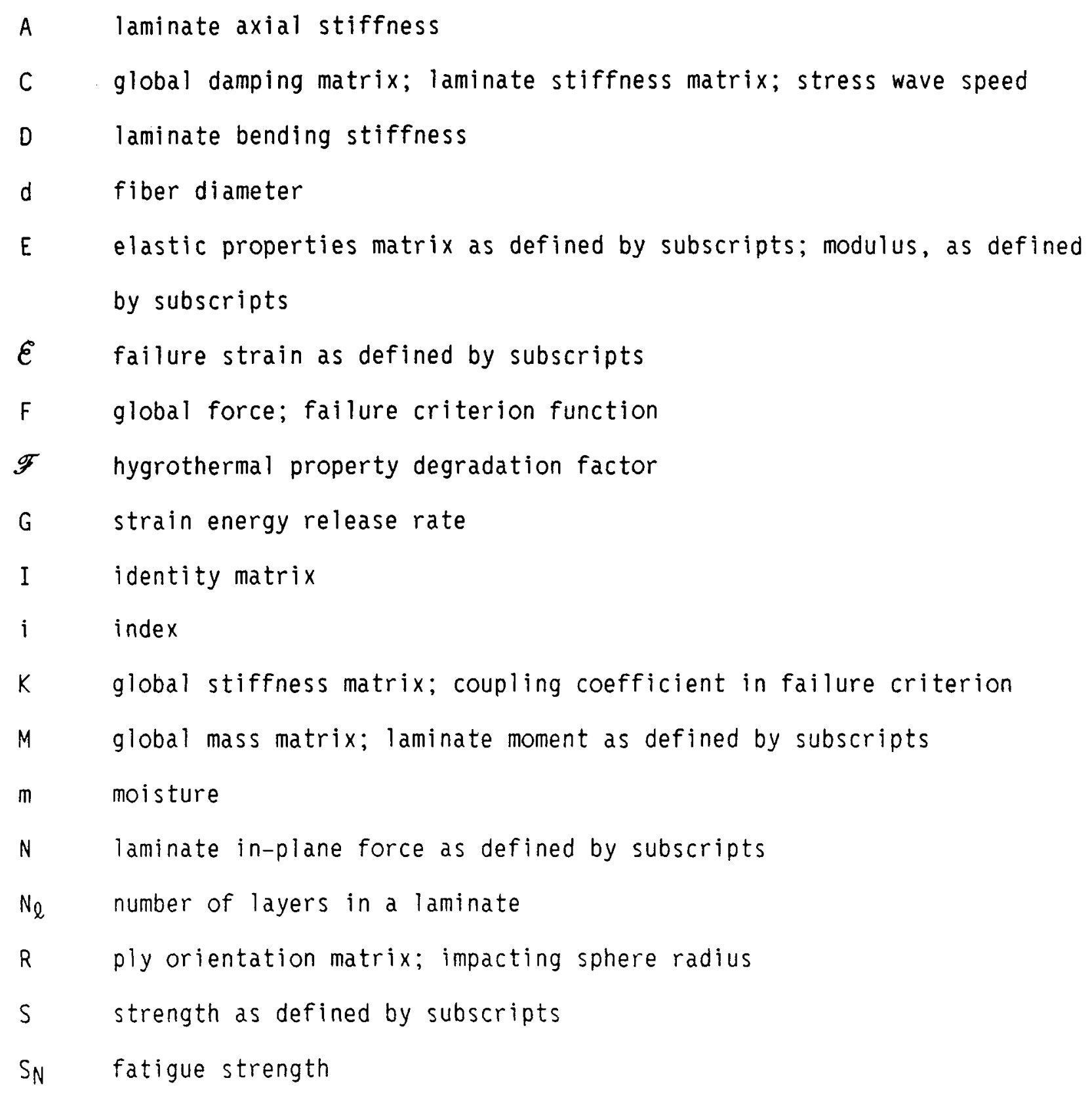




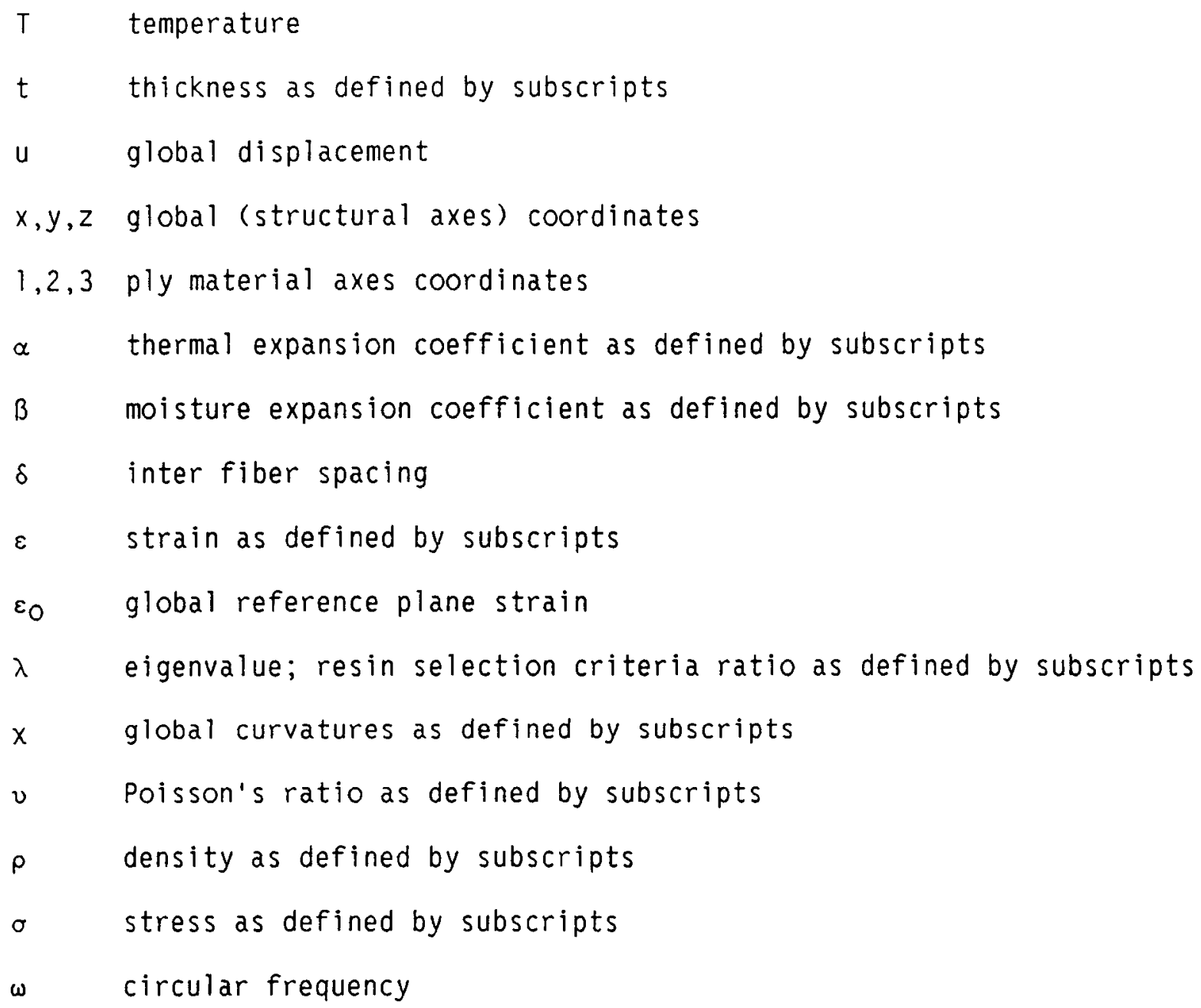


123 ply material axes respective properties

$\alpha \quad$ T-tension or C-compression

B T-tension or C-compression

Matrices

[ ] array, matrix

vector, column matrix

[]$^{-1}$ matrix inverse

[ $]^{\top}$ matrix transpose

COMPOSITE MECHANICS: INHERENT SCALES AND DISCIPLINES

The various composite scales correspond to the way the composite is made. A schematic illustrating how a polyimide composite blade is made is shown in Fig. 1. The scales may be visualized as the dimension (homogenization dimension) within which the heterogeneous local structure is described and integrated. Within this scale, the individual constituents are homogenized. Referring to Fig. 1, the micromechanics scale is the fiber spacing within the unidirection composite (after in situ polymerization, Fig. 1). The macromechanics scale is the ply thickness since the ply material - axis may be rotated to provide the desired properties about the structural axes (broad goods and p.ly cutting, Fig. 1). The laminate theory scale is the laminate thickness which is an integral multiple of ply thickness. Within this scale the heterogeneous layered structure (made of plies and interply layers) is homogenized into a composite laminate (stacking of plies, fig. 1). The structural mechanics scale is several times the laminate thickness (finished blade, Fig. 1). Therefore, these are the four important scales within which the various composite mechanics disciplines are formulated. 
The various composite mechanics disciplines that have evolved to describe/study composite behavior may be grouped into those listed in Table 1. The respective scales and homogenization dimensions are summarized in Table 2. The math model sophistication for each discipline, including region modeled and key assumptions made, are summarized in Table 3 . Continuum mechanics includes theory of elasticity, plasticity as well as related subjects, for example fatigue and defect growth.

Several of the composite mechanics disfiplines have been integrated into computer codes. These codes generally simulate the composite behavior at its various scales. How the integration can be implemented in a code is schematically shown in Fig. 2 .

The left part of Fig. 2 depicts the upward integration (synthesis) of constituent material behavior through the successively larger composite scales and up to the structure. The right part depicts the downward traced (decomposition) of the structural behavior through the progressively smaller composite scales and down to the constituent material space $(P=$ $f(\sigma, T, m))$. This figure pictorially represents the major disciplines of composite mechanics and parallels the fabrication process in Fig. 1. The combined stress failure criteria, singularity mechanics, and life/durability disciplines (Table 2) generally need the composite behavior (stresses, strains, displacements) predicted by this type of integrated computer code at the various scales. The results presented and discussed later were obtained using such a code [1].

COMPOSITE MECHANICS: WHERE HAS IT BEEN? WHAT HAS IT ACCOMPLISHED?

A summary of where composite mechanics has been and what has been accomplished by using it is presented in Table 4 . The summary, expectedly, is presented in qualitative terms. It includes: (1) research conducted on that 
discipline; (2) success achieved - to the extent that the research has suceeded in providing the formalisms to understand and/or quantify the composite behavior with which the discipline is dealing; and (3) application how extensively the composites community is using that discipline.

It is worth noting that those disciplines which have received rather minimal amount of research are used most extensively. The reasons are: (1) the theoretical fundamentals are easily understood - follow classical mechanics; (2) the application is relatively straight forward; and (3) the predicted results correlate with measured data.

The results to be presented subsequentiy were selected to demonstrate, to some extent, the qualitative evaluation summarized in Table 4.

\section{Composite Micromechanics}

A schematic on which composite micromechanics can be based is shown in Fig. 3. The concepts depicted in this figure in conjunction with mechanics principles and assuming integrated average behavior leads to the type of micromechanics equations summarized in Fig. 4 [2]. A complete set of ply hygrothermomechanical behavior relationships is summarized in Fig. 5 . Comparisons of normalized results predicted by using the equations in Fig. 4 with measured data are shown in Fig. 6 for several intrapiy hybrid composites. As can be seen, the comparisons are generally in good agreement. A noticeable exception is the shear modulus (SM). This modulus is difficult to measure accurately; this may account for apparent discrepanies.

Micromechanics equations for piy uniaxial strengths are summarized in Fig. 7 [3]. Comparisons with measured data are shown in Fig. 8 for the same intraply hybrids as in Fig. 6. The comparisons are also in generally good agreement. The data in Figs. 6 and 8 are from Ref. 4. 
Predicted results inciuding hygrothermal effects are shown in Fig. 9 [5]. Again, the agreement is very good considering the complexity of the composite behavior simulated by the relatively simple equations. Collectively, the comparisons shown in Figs. 5, 6, 8, and 9 demonstrate that micromechanics predict unidirectional composite behavior within "acceptable engineering accuracy". Acceptable engineering accuracy is used herein to mean that the agreement between predicted results and measured data is considered to be as good as can be expected based on engineering judgement and on considerations of the complexities and uncertainties involved.

Composite Macromechanics

The composite macromechanics discipline has generated the equations to predict off-axis (unidirectional composites loaded at an angle to the fiber direction) properties when the properties about the material axes are known. These equations are summarized in Fig. 10 in matrix form [6]. The schematic in this figure defines the two coordinate axes and the rotation. Results predicted by these equations are compared with measured data in Figs. 11 and 12 [7]. As can be seen, the agreement is very good. What is more significant about these comparisons is that properties about the material axes were predicted using the micromechanics equations described previously.

Combined Stress Failure Criteria

An expanded form of a combined stress failure criterion equation including hygrothermal and constant amplitude cyclic load effects is shown in Fig. 13 [6]. Results predicted from this equation are compared with measured data in Fig. 14 [7]. The data is at room temperature, dry monotonic load conditions. The agreement is excellent. 


\section{Laminate Theory}

A form of laminate theory equations are summarized in Fig. 15 [1]. Results predicted by using these equations are compared with measured data in Table 5 [8] for moduli and Poisson's ratios. The agreement is better than 10 percent except for two of the in plane shear moduli. It is well known that measuring composite shear properties is a rather delicate task. Uncertainties in measured data are just as much in question for these types of tests as are some of the assumptions made in deriving laminate theory equations. Laminate strength (stress at fracture) predicted by linear laminate theory (equations Fig. 15) in combination with combined stress failure criteria (equations similar to that in Fig. 13) are compared with measured data in Fig. 16 [8]. The data in this figure is for three different laminates subjected to five different load conditions and tested at hot-wet environmental conditions. The spread in the predicted results is for two cases: (1) first ply failure - lower bound and (2) last ply failure - upper bound. It is very important to observe that the predicted lower bound (first ply failure) is below the lowest measured data for the majority of the cases. Needless to say, the agreement is well within acceptable engineering accuracy. Laminate fracture stress predictions for a composite thin tube subjected to combined tension and torsion (Fig. 17) are compared in Table 6 [9]. The agreement is excellent and what is even more important, the predicted upper bound is below the measured data. It is accepted within the composites community that linear laminate theory for first-ply-failure tends to predict conservative fracture stresses for the laminate. This is consistent with the results shown in Table 6 . 


\section{Singularity Mechanics}

Singularity mechanics in composites has received and continues to receive substantial research attention. Singularity mechanics is required in order to determine stress concentrations in the vicinity of: (1) defects (cracks, holes, delaminations, ply drops); (2) free-edge interlaminar planes; (3) joints; (4) load applications; and (5) support conditions. The level of sophistication for composite singularity mechanics varies from the simple net-section-area stress, to anisotropic elasticity, to three-dimensional finite difference or finite element analysis.

The equations for predicting the hoop stress concentration in the periphery of a circular hole in an anisotropic infinite plate due to in-plane loads are shown in Fig. 18 [6]. These equations are significant since measured data show that the stress concentration in crack-like defects is similar to a circular hole with equivalent diameter (Fig. 19, [6]). It may be concluded, therefore, that laminate defect stress concentrations are readily estimated within acceptable engineering accuracy, using closed form equations for equivalent diameter circular holes in infinite anisotropic plates.

Stress singularity fields near free edges, near interlaminar delaminations, and near transply cracks are frequently evaluated using appropriate three-dimensioal finite element analyses. Representative results obtained from these analyses are shown in Fig. 20 [10] for free-edge and in Fig. 21 [11] for interlaminar delamination. The corresponding local failure modes induced by these stress fields, cumulative damage, and subsequent progressive fracture will be discussed later.

\section{Life/Durability}

Life/durability is generally used to describe how long a composite structure with inadvertent defects will survive in its monotonic or cyclic 
load service environment. Fracture toughness and damage tolerance are equivalently used to imply life/durability. Both of these equivalent terms seek to answer one or more of the following important questions: (1) what is the number of load cycles. which will induce structural fracture in a composite without and/or with assumed defects? (2) what is the critical size that an assumed defect will grow to for imminent structural fracture under applied service loading conditions? and ( 3 ) what is the defect size that a loaded composite structure can safely withstand? The first two questions are associated with the life/durability under cyclic loads; while the third question is associated with a suddenly induced damage and it is traditionally considered a composite material characterstic. The answers to all three questions are clearly structural, since they require simultaneous consideration of composite material, laminate configuration structure, and loading conditions.

The results summarized in Fig. 22 [12] are an answer to the first question. These were obtained using a procedure which consists of a simplified composite mechanics model in conjunction with empirical data [12]. This procedure can be used to quantify laminate configuration and/or loading environment effects on laminate life/durability. The answer to the second question requires evaluation of local damage occurrence, cumulative damage, and progressive fracture. This evaluation is, by necessity, performed by developing and using sophisticated and integrated computer codes such as CODSTRAN (COmposite Durability STRuctural ANalysis, [13]). Results obtained using CODSTRAN are compared with measured data in Fig. 23 [13]. As can be observed, the agreement is well within acceptable engineering accuracy. The 
local failure modes contributing to damage growth are summarized in Table 7 [14]. Clearly CODSTRAN can be used to computationally simulate the local damage occurrence, cumulative damage, and progressive fracture.

The answer to the third question is obtained by evaluating what is defined herein as "Composite Structure Fracture Toughness." Composite structure fracture toughness is predicted by using composite mechanics in conjunction with fracture mechanics concepts and with finite element analysis. The general procedure is summarized in Fig. 24 [11]. Representative results obtained are shown in Fig. 25 [11] where ranges of measured data are also included. The importance of composite mechanics in answering the third question is far reaching. It makes it possible to quantify composite damage tolerance in terms of two easily identifiable fracture toughness parameters: strain energy release rate and defect size (crack length).

It is worth noting that the use of composite mechanics in conjunction with finite element analysis in order to computationally simulate composite life/durability (fracture - toughness/damage-tolerance) is a recent and evolving development. The traditional practice to evaluate these is the use of appropriate experiments.

\section{Structural Analysis}

The governing equations for composite structural analysis are summarized in Fig. 26 in matrix form. These equations are embedded in general purpose structural analysis codes. Composite mechanics are used to generate all the material properties required in these equations. Representative results obtained for the natural frequencies of a hybrid composite fan blade (Fig. 26) are summarized and compared with measured data in Table 8 [15] and in Fig. 27 [15] for results obtained for impact response. The agreement is very good. 
The fan blade was selected to illustrate the effectiveness of composite mechanics in describing composite behavior at all scale levels and including interply and intraply hybrids as well as a metallic leading edge device. The composite mechanics used, in this case, is integrated into a computer code COBSTRAN (COmposite Blade STRuctural ANalysis, [16]). A unique feature in this code is its resident constituent materials databank where the properties of a large number of fibers and matrices are available. This databank, composite micromechanics and laminate theory make it possible to simulate all types of composites and even combinations with metals. It is the good agreement with measured data (Table 8 and Fig. 27) that has led to the extensive use of composite structural analysis noted in Table 4.

The prediction of life/durability of composite structures generally requires extensive use of composite structural analysis. The structural analysis is used to predict the global structural response (displacements, frequencies, buckling, etc.) while singularity mechanics and methods described in the last section are used to predict local behavior including dominant failure modes.

COMPOSITE MECHANICS: WHERE IS IT HEADED? WHERE SHOULD IT GO? Where composite mechanics is headed (based on recent research emphasis) and where it should go (author's personal view) are summarized in Table 9 for the seven different disciplines. As can be seen in Table 9 , the trends for where it is going are: (1) traditional, classical, or conventional; (2) mostly negligible anticipated research effort; and (3) major emphasis on user familiarity with available general purpose finite element codes. Singularity mechanics, and life/durability however, will continue to receive considerable classical and/or semiconventional attention. 
On the other hand, the author sees need for balanced research in all the disciplines. This research should focus on developing methods and criteria for: (1) fracture initiation and propagation at all scale levels; (2) combined mode fracture and mode tracking; (3) in situ ply strengths and failure mode branching; (4) three-dimensional behavior with detailed account of local heterogeneities and nonlinearities; (5) environmental (moisture/temperature) effects; (6) composite mechanics, specialty finite elements and substructuring techniques for all scale levels; and (7) dedicated, self-adaptive, expert-system-driven algorithms for enhanced computational efficiency while retaining acceptable engineering accuracy in the predicted results. The development of these methods will more than likely require innovative, creative, and even revolutionary thinking in order to introduce the new variables that define/describe the local physics. Two illustrative examples in this direction are: the effect of interlaminar delamination on natural frequencies (Fig. 28) and a rectangular array with an off-center fiber for formulating micromechanics (Fig. 29).

\section{CONCLUSIONS}

A personal, but representative, assessment of composite mechanics has been presented. The assessment is presented by grouping composite mechanics into seven disciplines: (1) micromechanics; (2) macromechanics; (3) combined stress failure; (4) laminate theory; (5) singularity mechanics; (6) life/durability; and (7) structural analysis. The scale levels associated with each discipline and the various levels of sophistication of composite math models in each discipline are described. What has been accomplished in each discipline, emphasis on current research, and future trends are summarized. The future trends are mainly conventional. Greater progress will be achieved by pursuing unconventional and innovative methods which are 
dedicated, adaptive, and expert-system-driven. Composite mechanics spans many disciplines with each playing a very significant role in its future growth and success. Successful contributions, which are timely and cost-effective, will require the collective/coordinated research efforts of experts from these disciplines.

\section{REFERENCES}

[1] Murthy, P.L.N. and Chamis, C.C., "ICAN: Integrated Composites Analyzer," NASA Report TM-83700, National Aeronautics and Space Administration, Washington, DC, 1984.

[2] Chamis, C.C., "Simplified Composite Micromechanics Equations for Hygral, Thermal and Mechanical Properties," SAMPE Quarterly, Vol. 15, Apr. 1984, pp. 14-23. (NASA Report TM-83320, National Aeronautics and Space Administration, Washington, DC, 1983.)

[3] Chamis, C.C., "Simplified Composite Micromechanics Equations for Strength, Fracture Toughness, and Environmental Effects," NASA Report TM-83696, National Aeronautics and Space Administration, Washington, DC, 1984.

[4] Chamis, C.C., Lark, R.F., and Sinclair, J.H., "Mechanical Property Characterization of Intraply Hybrid Composites," NASA Report TM-79306, National Aeronautics and Space Administration, Washington, DC, 1979.

[5] Chamis, C.C. and Sinclair, J.H., "Durability/Life of Fiber Composites in Hygrothermomechanical Environments," in Composite Materials: Testing and Design, ASTM, Philadelphia, PA, 1982, pp. 498-512. (NASA Report TM-82749, National Aeronautics and Space Administration, Washington, DC, 1981.)

[6] Chamis, C.C. and Smith, G.T., "Resin Selection Criteria for Tough Composite Structures," AIAA Journal, Vol. 23, June 1985, pp. 902-911. (NASA Report TM-83449, National Aeronautics and Space Administration, Washington, DC, 1983.) 
[7] Chamis, C.C. and Sinclair, J.H., "Mechanical Behavior and Fracture Characteristics of Off-Axis Fiber Composites: II-Theory and Comparisons," NASA Report TP-1082, National Aeronautics and Space Administration, Washington, DC, 1978 .

[8] Chamis, C.C., Lark R.F., and Sinclair, J.H., "An Integrated Theory for Predicting the Hygrothermomechanical Response of Advanced Composite Structural Components," NASA Report TM-73812, National Aeronautics and Space Administration, Washington, DC, 1977.

[9] Chamis, C.C. and Sullivan, T.M., "Combined-Load Stress-Strain Relationships for Advanced Fiber Composites," NASA Report TM-X-71825, National Aeronautics and Space Administration, Washington, DC, 1976.

[10] Murthy, P.L.N. and Chamis, C.C., "A Study of Interply Layer Effects on the Free Edge Stress Field of Angleplied Laminates," Computers and Structures, Vol. 20, No. 1-3, 1985, pp. 431-441. (NASA Report TM-86924, National Aeronautics and Space Administration, Washington, DC, 1984.)

[11] Murthy, P.L.N. and Chamis, C.C., "Interlaminar Fracture Toughness: Three-Dimensional Finite-Element Modeling for End-Notch and Mixed Mode Flexure," NASA Report TM-87138, National Aeronautics and Space Administration, Washington, DC, 1985.

[12] Chamis, C.C. and Ginty, C.A., "Composite Durability and Damage Tolerance: Simplified Predictive Methods," NASA Report TM-100179, National Aeronautics and Space Administration, Washington, DC, 1987.

[13] Chamis, C.C. and Smith, G.T., "CODSTRAN: Composite Durability Structural Analysis," NASA Report TM-79070, National Aeronautics and Space Administration, Washington, DC, 1978. 
[14] Irvine, T.B. and Ginty, C.A., "Progressive Fracture of Fiber Composites," Journal of Composite Materials, Vol. 20, Mar. 1986, pp. 166-184. (NASA

Report TM-83701, National Aeronautics and Space Administration, Washington, DC, 1983.)

[15] Chamis, C.C. and Sinclair, J.H., "Analysis of High Velocity Impact on Hybrid Composite Fan Blades," NASA Report TM-79133, in Structures, Structural Dynamics, and Materials, AIAA, New York, 1979, pp. 249-257. (National Aeronautics and Space Administration, Washington, DC, 1979.)

[16] Chamis, C.C. and Lynch, J.E., "High-Tip-Speed Fiber Composite Fan Blades: Vibration and Strength Analysis,: NASA Report TM-X-71589, National Aeronautics and Space Administration, Washington, DC, 1974.

TABLE 1. - COMPOSITE MECHANICS DESCIPLINES

Micromechanics - Intraply heterogeneity
Macromechanics - Ply homogenization
Combined stress failure criteria - Five strengths
Laminate theory - Layered anisotropic medium
Singularity mechanics - Stress concentrations
Life/durability - Cumulative damage and propagation
Structural mechanics - Composite or laminate homogenization


TABLE 2. - COMPOSITE MECHANICS SCALE LEVELS

\begin{tabular}{|c|c|c|}
\hline Disciplines & Scale & $\begin{array}{l}\text { Homogenization ratio, } \\
\text { fiber diameters (F.D.) }\end{array}$ \\
\hline Micromechanics & Fiber diameter & 1.2 F.D. (FVR $=0.6)$ \\
\hline Macromechanics & Ply thickness & $\begin{array}{c}15 \text { F.D. (except } \\
\text { boron/epoxy) }\end{array}$ \\
\hline $\begin{array}{l}\text { Combined stress } \\
\text { failure criteria }\end{array}$ & Ply thickness & $\begin{array}{l}15 \text { F.D. (except } \\
\text { boron/epoxy) }\end{array}$ \\
\hline Laminate theory & $\begin{array}{l}\text { Laminate thickness } \\
\text { interply layer } \\
\text { thickness }\end{array}$ & $\begin{array}{l}\text { Multiples of ply thickness } \\
15 \mathrm{~F} . \mathrm{D} \text {. and greater }\end{array}$ \\
\hline Singularity mechanics & Infinitesimal & $<<$ Fiber diameter \\
\hline Life/durability & Ply thickness & $\begin{array}{c}15 \text { F.D. (except } \\
\text { boron/epoxy) }\end{array}$ \\
\hline Structural mechanics & $\begin{array}{l}\text { Laminate thickness } \\
\text { finite element } \\
\text { size }\end{array}$ & $\begin{array}{l}\text { Many times the laminate } \\
\text { thickness }\end{array}$ \\
\hline
\end{tabular}

TABLE 3. - COMPOSITE MECHANICS MATH MODEL SOPHISTICATION

\begin{tabular}{|c|c|c|c|}
\hline Discipline & $\begin{array}{l}\text { Region } \\
\text { modeled }\end{array}$ & $\begin{array}{c}\text { Key } \\
\text { assumption(s) }\end{array}$ & Math model \\
\hline Micromechanics & $\begin{array}{l}\text { Single fiber } \\
\text { array }\end{array}$ & $\begin{array}{l}\text { No interface } \\
\text { or thotropic } \\
\text { constituents }\end{array}$ & $\begin{array}{l}\text { Mechanics of materials } \\
\text { continuum mechanics } \\
\text { finite element }\end{array}$ \\
\hline Macromechanics & Continuum & $\begin{array}{l}\text { Homogeneous } \\
\text { or thotropic }\end{array}$ & Mechanics of materials \\
\hline $\begin{array}{l}\text { Combined stress } \\
\text { failure }\end{array}$ & Continuum & $\begin{array}{l}\text { Homogeneous } \\
\text { orthotropic }\end{array}$ & $\begin{array}{l}\text { Continuum mechanics } \\
\text { five inplane strength }\end{array}$ \\
\hline Laminate theory & $\begin{array}{l}\text { Line through } \\
\text { thickness }\end{array}$ & $\begin{array}{l}\text { Anisotropic layers } \\
\text { no interply layer }\end{array}$ & $\begin{array}{l}\text { Mechanics of materials } \\
\text { finite element }\end{array}$ \\
\hline $\begin{array}{l}\text { Singuiarity } \\
\text { mechanics }\end{array}$ & Continuum & Anisotropic & $\begin{array}{l}\text { Continuum mechanics } \\
\text { finite element } \\
\text { finite difference }\end{array}$ \\
\hline Life/durability & Continuum & Orthotropic & "Fracture" mechanics \\
\hline $\begin{array}{l}\text { Structural } \\
\text { mechanics }\end{array}$ & Continuum & An isotropic & $\begin{array}{l}\text { Structural mechanics } \\
\text { finite element }\end{array}$ \\
\hline
\end{tabular}


TABLE 4. - COMPOSITE MECHANICS

[Where has it been? What has it accomplished?]

\begin{tabular}{|c|c|c|c|}
\hline Discipline & $\begin{array}{l}\text { Research } \\
\text { conducted }\end{array}$ & $\begin{array}{l}\text { Success } \\
\text { (understood/ } \\
\text { quantified) }\end{array}$ & Application \\
\hline $\begin{array}{l}\text { Composite } \\
\text { micromechanics }\end{array}$ & Considerable & Partial & Limited \\
\hline $\begin{array}{l}\text { Composite } \\
\text { macromechanics }\end{array}$ & Negligible & Exceptional & Extensive \\
\hline $\begin{array}{l}\text { Combined stress } \\
\text { failure }\end{array}$ & Minimal & Noticeable & Extensive \\
\hline Laminate theory & Considerable & Acceptable & Extensive \\
\hline $\begin{array}{r}\text { Singularity } \\
\text { mechanics }\end{array}$ & Substantial & Promising & Limited \\
\hline Life/durability & Substantial & Promising & Limited \\
\hline $\begin{array}{l}\text { Structural } \\
\text { mechanics }\end{array}$ & Minimal & Highly acceptable & Extensive \\
\hline
\end{tabular}

TABLE 5. - COMPARISON OF MEASURED AND PREDICTED ELASTIC PROPERTIES OF ANGLEPLIED LAMINATES

[AS/3501-5 with 1.8 percent moisture and room temperature.]

\begin{tabular}{|c|c|c|c|c|}
\hline Laminate & $\begin{array}{l}\text { Longitudinal } \\
\text { modulus, MSI }\end{array}$ & $\begin{array}{l}\text { Transverse } \\
\text { modulus, } \\
\text { MSI }\end{array}$ & $\begin{array}{l}\text { Shear } \\
\text { Modulus, } \\
\text { MSI }\end{array}$ & $\begin{array}{l}\text { Major } \\
\text { Poisson's } \\
\text { Ratio }\end{array}$ \\
\hline \multicolumn{5}{|l|}{$\left[0 / \pm 45_{2} / 0 / \pm 45\right]_{S}$} \\
\hline Measured & 6.3 & 3.08 & 3.21 & 0.803 \\
\hline Predicted & 6.3 & 3.2 & 3.80 & .781 \\
\hline $\begin{array}{l}\text { Percent } \\
\text { difference }\end{array}$ & 0 & +3.9 & +18.4 & -2.70 \\
\hline \multicolumn{5}{|c|}{$\left[0_{2} / \pm 45 / 0_{2} / 90 / 0\right]_{S}$} \\
\hline Measured & 13.0 & 4.2 & 1.5 & 0.325 \\
\hline Predicted & 13.0 & 4.5 & 1.6 & .318 \\
\hline $\begin{array}{l}\text { Percent } \\
\text { difference }\end{array}$ & 0 & +7.1 & +6.7 & -2.2 \\
\hline \multicolumn{5}{|l|}{$\left[(0 / \pm 45 / 90)_{2}\right]_{S}$} \\
\hline Measured & 6.68 & 6.62 & 2.34 & 0.350 \\
\hline Predicted & 7.20 & 7.20 & 2.70 & .333 \\
\hline $\begin{array}{l}\text { Percent } \\
\text { difference }\end{array}$ & +7.8 & +8.7 & 15.4 & -4.8 \\
\hline
\end{tabular}


TABLE 6. - COMPARISON OF FRACTURE STRESSES

[The specimen was loaded to fracture in combined axial compression and torsional loading condition.]

\begin{tabular}{|l|c|c|c|}
\hline \multirow{2}{*}{ Stress type } & \multicolumn{3}{|c|}{ Stress value, KSI } \\
\cline { 2 - 4 } & Measured & \multicolumn{3}{|c|}{ Predicted } \\
\cline { 3 - 4 } & & Lower bound & Upper bound \\
\hline Axial & 20.2 & 17.9 & 19.4 \\
Torsional & 23.1 & 20.6 & 22.3 \\
\hline
\end{tabular}

TABLE 7. - FRACTURE MODES ${ }^{\alpha}$ OF $[ \pm \theta]_{S}$ G/E LAMINATES

[Predicted by Codstran.]

\begin{tabular}{|c|c|c|c|c|c|c|c|c|c|c|}
\hline \multirow[t]{2}{*}{ Notch type } & \multicolumn{10}{|c|}{ Ply orientation; $[ \pm \theta]_{S} ; \theta$ in degrees } \\
\hline & 0 & 3 & 5 & 10 & 15 & 30 & 45 & 60 & 75 & 90 \\
\hline $\begin{array}{l}\text { Unnotched -- } \\
\text { solid }\end{array}$ & LT & $\begin{array}{l}L T \\
S^{3}\end{array}$ & $\begin{array}{l}\text { LT } \\
S^{3}\end{array}$ & $\begin{array}{l}\mathrm{LT} \\
\mathrm{S}^{3}\end{array}$ & $\begin{array}{l}\text { I } \\
\text { S }\end{array}$ & $S$ & $\begin{array}{l}\text { I } \\
S\end{array}$ & $\begin{array}{l}\text { TT } \\
--\end{array}$ & TT & $\begin{array}{l}\text { TT } \\
--\end{array}$ \\
\hline Notched -- & sl & $s^{1}$ & $s^{1}$ & $\mathrm{~S}$ & S & $1^{4}$ & $\mathrm{I}^{4}$ & $\mathrm{I}^{4}$ & TT & TT \\
\hline $\begin{array}{l}\text { through } \\
\text { slit }\end{array}$ & LT & LT & $\mathrm{LT}$ & -- & -- & S & $S$ & $\begin{array}{l}\text { TT } \\
S^{2}\end{array}$ & -- & -- \\
\hline Notched -- & $s^{1}$ & $s^{1}$ & $s^{1}$ & $\mathrm{~S}$ & $\mathrm{~S}$ & $I^{4}$ & $I^{4}$ & $I^{4}$ & TT & TT \\
\hline $\begin{array}{l}\text { through } \\
\text { hole }\end{array}$ & LT & LT & LT & -- & LT & $\mathrm{s}$ & $\begin{array}{l}\text { S } \\
T T\end{array}$ & $T T$ & $-\sim$ & -- \\
\hline
\end{tabular}

$a_{L T}=$ Longitudinal tension.

$T T=$ Transverse tension.

$S=$ Intraply shear.

Numbers denote failure modes as follows:

(1) initial fracture due to intrapiy shear in the notch tip zone

(2) minimal intraply shearing during fracture

(3) some intraply shear occurring near constraints (grips)

(4) delaminations occur in notch tip zone prior to any intraply damage

$I$ = Interply delamination. 
TABLE 8. - VIBRATION FREQUENCIES OF HYBRID COMPOSITE FAN BLADE

\begin{tabular}{|c|c|c|c|}
\hline Mode & Measured & Predicted & $\begin{array}{c}\text { Predicted/ } \\
\text { measured }\end{array}$ \\
\hline 1 & 62 & 64 & 1.03 \\
2 & 190 & 186 & .98 \\
3 & 288 & 303 & 1.05 \\
4 & 425 & 454 & 1.07 \\
5 & 667 & 653 & .98 \\
\hline
\end{tabular}

TABLE 9. - COMPOSITE MECHANICS

[Where is it headed? Where should it go?]

\begin{tabular}{|c|c|c|}
\hline Discipline & Effort/approach & $\begin{array}{l}\text { Should go } \\
\text { (personal view) }\end{array}$ \\
\hline $\begin{array}{l}\text { Composite } \\
\text { micromechanics }\end{array}$ & $\begin{array}{l}\text { Negligible } \\
\quad(\text { traditional) }\end{array}$ & $\begin{array}{l}\text { Fracture initiation } \\
\text { and propagation }\end{array}$ \\
\hline $\begin{array}{l}\text { Composite } \\
\text { macromechanics }\end{array}$ & $\begin{array}{l}\text { Negligible } \\
\text { (classical) }\end{array}$ & $\begin{array}{l}\text { Combined mode fracture } \\
\text { and mode tracking }\end{array}$ \\
\hline $\begin{array}{l}\text { Combined stress } \\
\text { failure }\end{array}$ & $\begin{array}{l}\text { Negligible } \\
\quad(\text { classical) }\end{array}$ & $\begin{array}{l}\text { In situ ply strengths and } \\
\text { failure mode branching }\end{array}$ \\
\hline $\begin{array}{l}\text { Laminate } \\
\text { theory }\end{array}$ & $\begin{array}{l}\text { Nonl inear } \\
\quad(\text { conventional) }\end{array}$ & $\begin{array}{l}\text { Increase computational } \\
\text { efficiency and three- } \\
\text { dimensional behavior }\end{array}$ \\
\hline $\begin{array}{l}\text { Singularity } \\
\text { mechanics }\end{array}$ & $\begin{array}{l}\text { Extensive } \\
\text { homogeneous anisotropy } \\
\text { (classical) }\end{array}$ & $\begin{array}{l}\text { Local heterogeneity and } \\
\text { nonlinearity }\end{array}$ \\
\hline Life/durability & $\begin{array}{l}\text { Progressive fracture } \\
\text { (semi conventional) }\end{array}$ & $\begin{array}{l}\text { Hygral, thermal, mechani- } \\
\text { cal, and temporal } \\
\text { aspects properly and } \\
\text { tractably integrated }\end{array}$ \\
\hline $\begin{array}{l}\text { Structural } \\
\text { mechanics }\end{array}$ & $\begin{array}{l}\text { Familiarity with available } \\
\text { GPFEC (user mode) } \\
\text { limited FE development }\end{array}$ & $\begin{array}{l}\text { Development of composite } \\
\text { mechanics specialty } \\
\text { finite elements and } \\
\text { substructuring methods }\end{array}$ \\
\hline
\end{tabular}




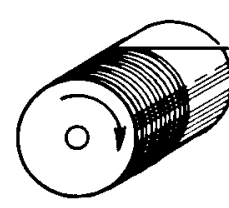

FIBER SPOOL

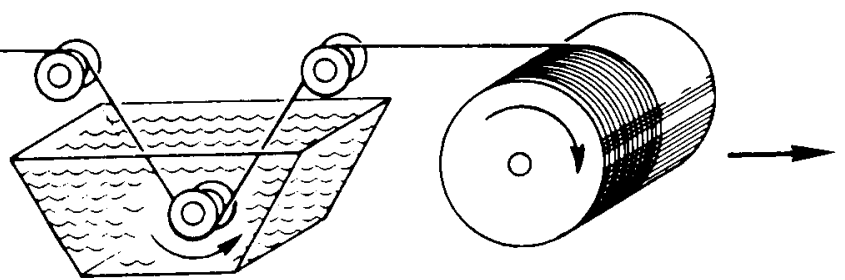

TAKEUP DRUM

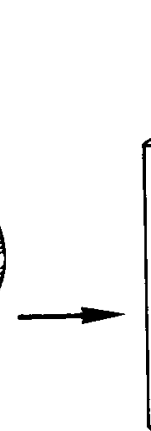

MONOMER SOLUTION

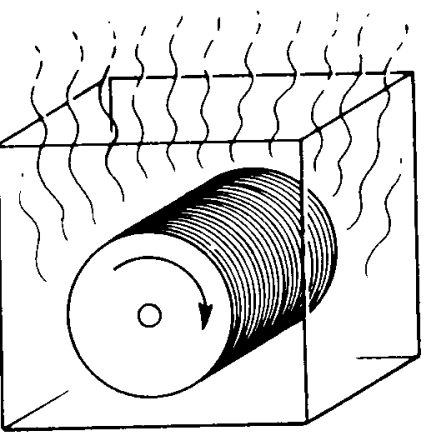

IN SITU POLYMERIZATION

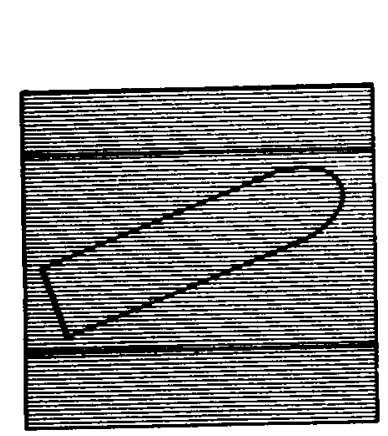

BROAD GOODS

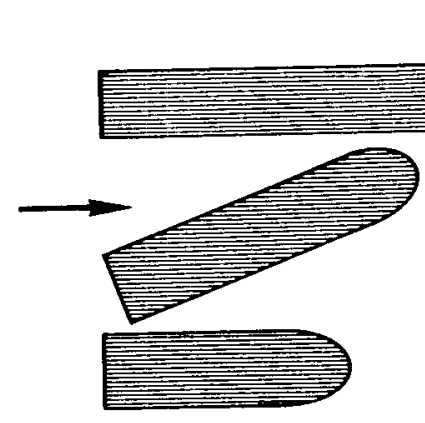

PLIES
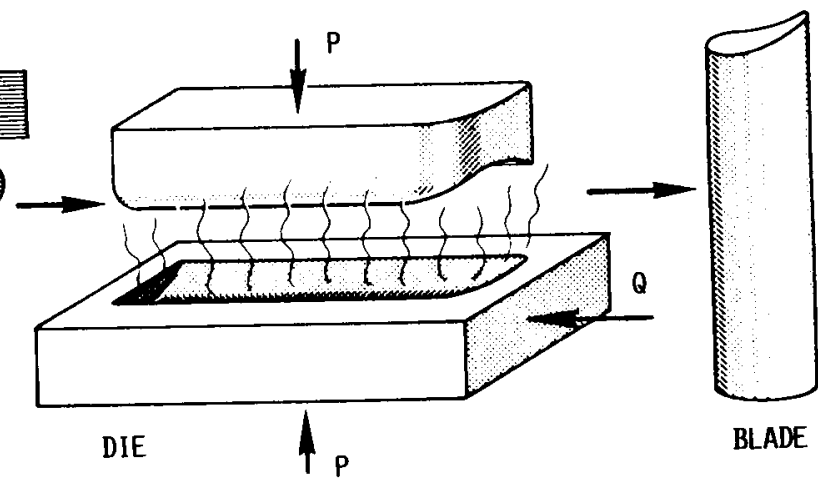

FIGURE 1. - PMR POLYIMIDE PROCESS.

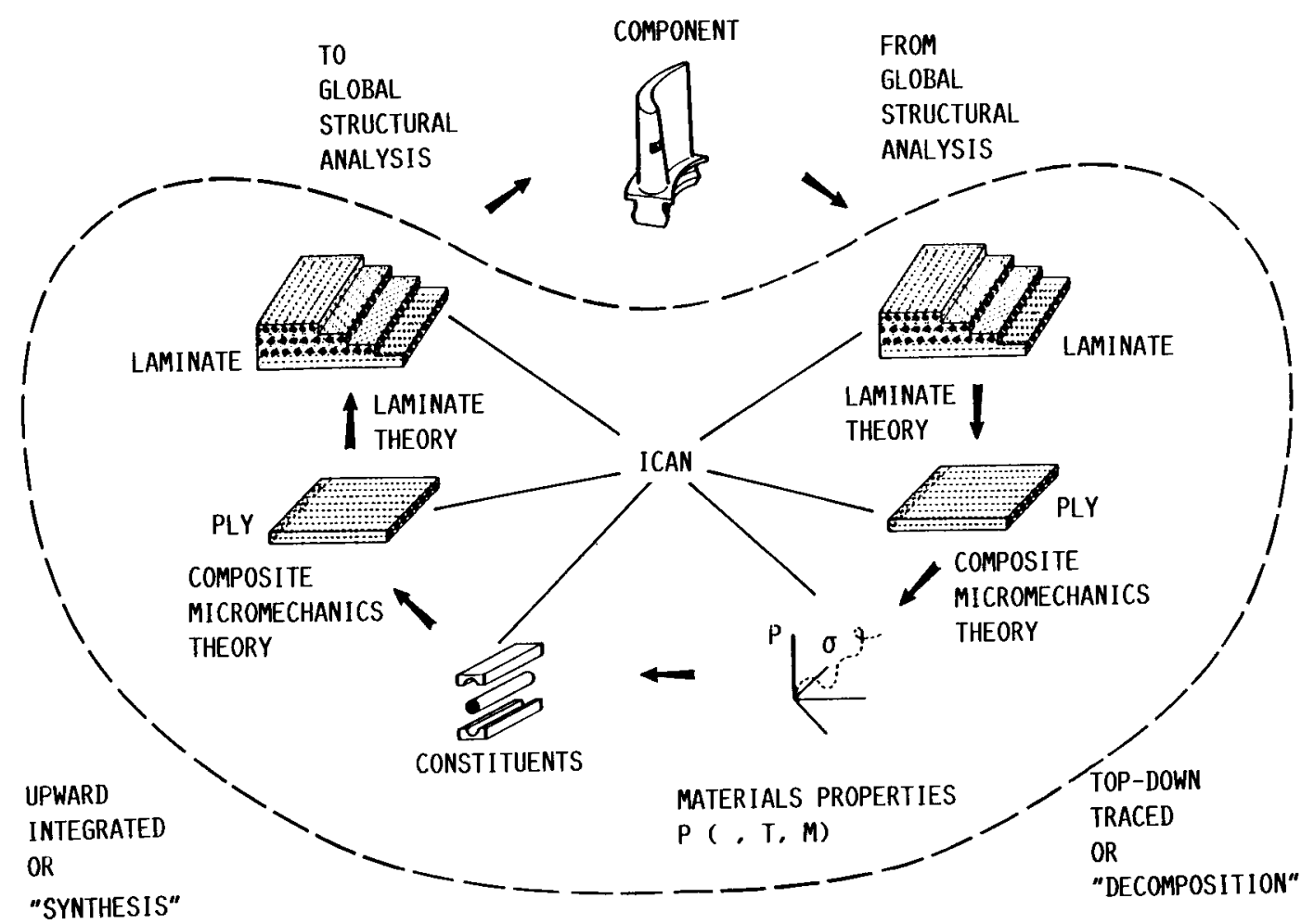

FIGURE 2. - ICAN: INTEGRATED COMPOSITES ANALYZER. 


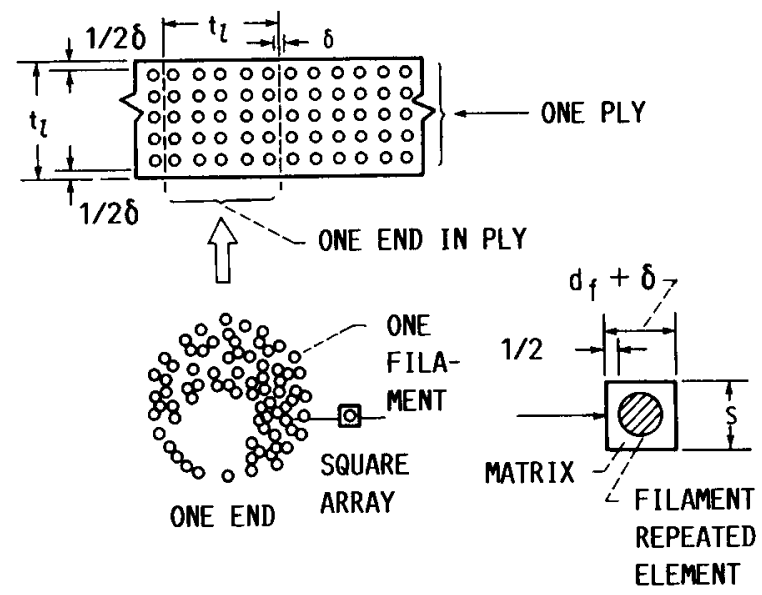

FIGURE 3. - SCHEMATIC OF PLY. INTERNAL GEOMETRIC RELATIONSHIPS.

$$
\begin{array}{ll}
\text { LONGITUDINAL MODULUS: } & E_{\ell 11}=k_{f} E_{f 11}+k_{m} E_{m} \\
\text { TRANSVERSE MODULUS: } & E_{\ell 22}=\frac{-E_{m}}{1-\sqrt{k_{f}}\left(1-E_{m} / E_{f 22}\right)}=E_{\ell 33} \\
\text { SHEAR MODULUS: } & G_{\ell 12}=\frac{G_{m}}{1-\sqrt{k_{f}}\left(1-G_{m} / G_{f 12}\right)}=G_{\ell 13} \\
\text { SHEAR MODULUS: } & G_{\ell 23}=\frac{G_{m}}{1-\sqrt{k_{f}}\left(1-G_{m} G_{f 23}\right)} \\
\text { POISSON'S RATI0: } & v_{\ell 12}=k_{f} v_{f 12}+k_{m} \nu_{m}=v_{\ell 13} \\
\text { POISSON'S RATI0: } & v_{\ell 23}=\frac{E_{\ell 22}-1}{2 G_{\ell 23}}
\end{array}
$$

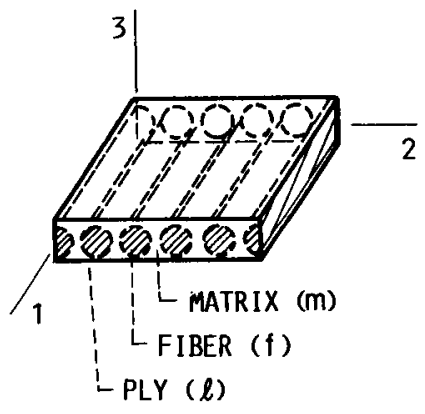

FIGURE 4. - COMPOSITE MICROMECHANICS, MECHANICAL PROPERTIES. 


\section{EXPANDED FORM:}

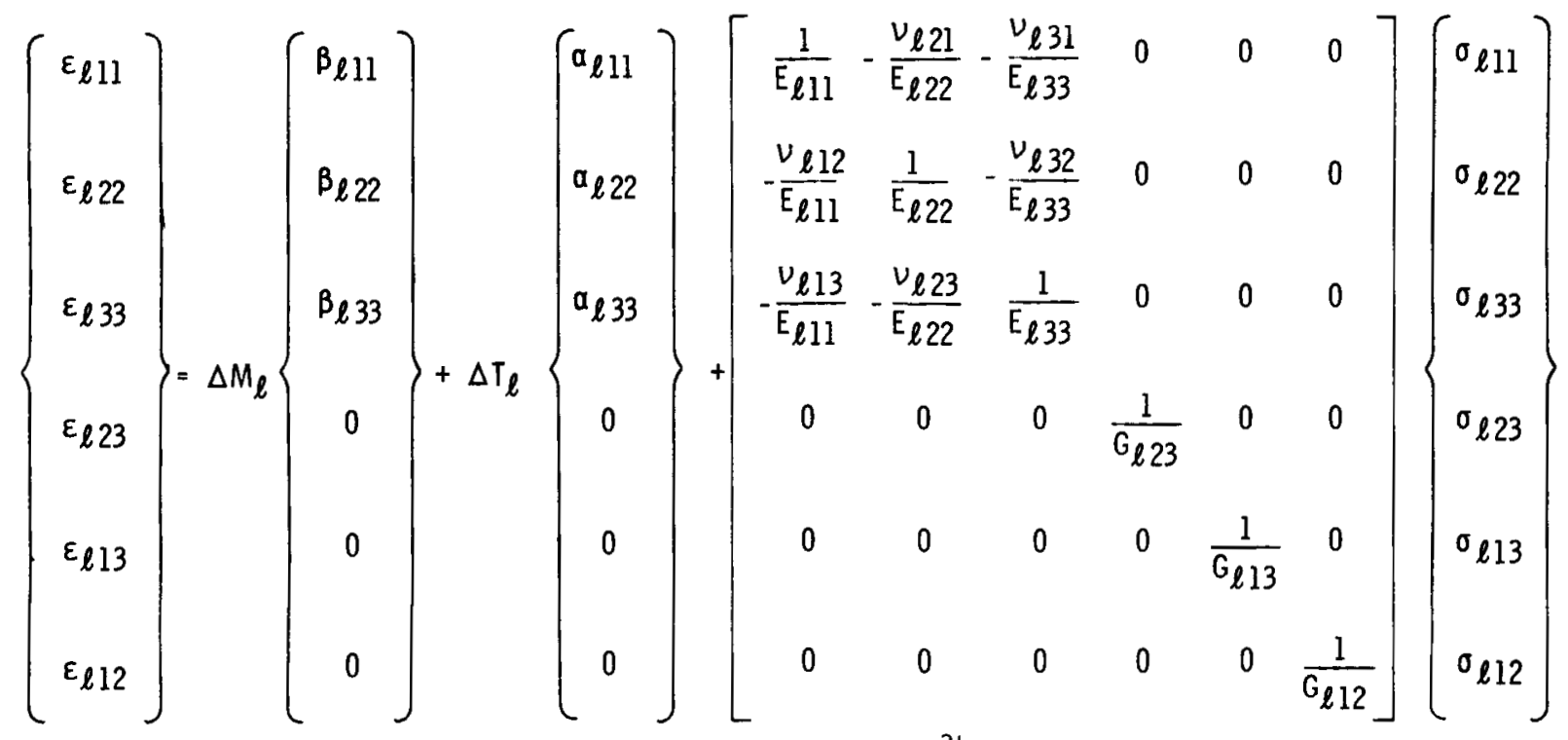

IN MATRIX FORM:

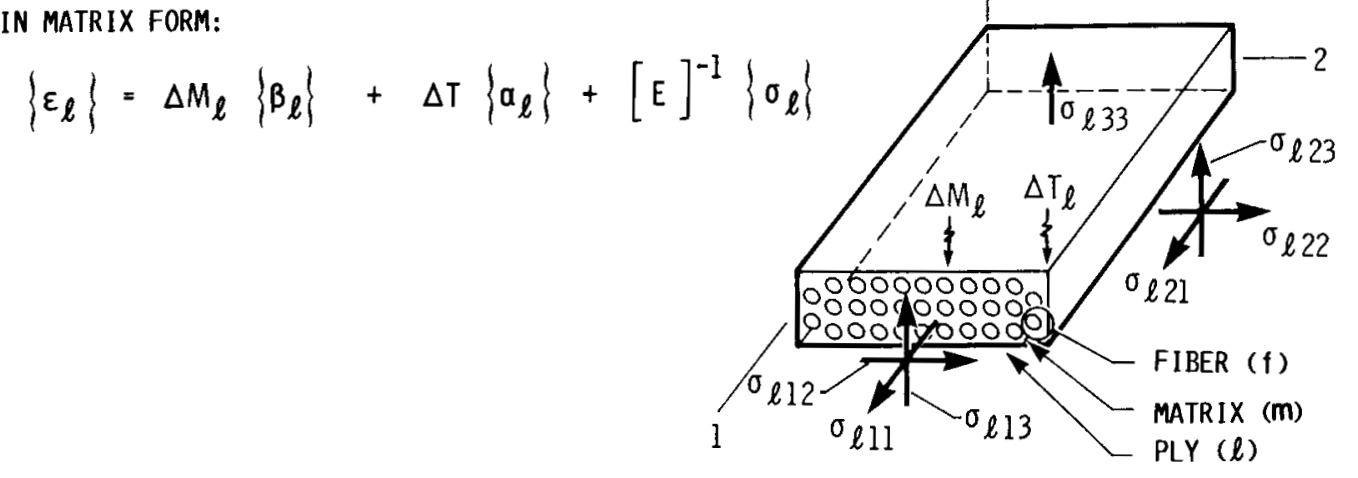

FIGURE 5. - PLY HYGROTHERMOMECHANICAL RELATIONSHIPS, LINEAR BEHAVIOR. 

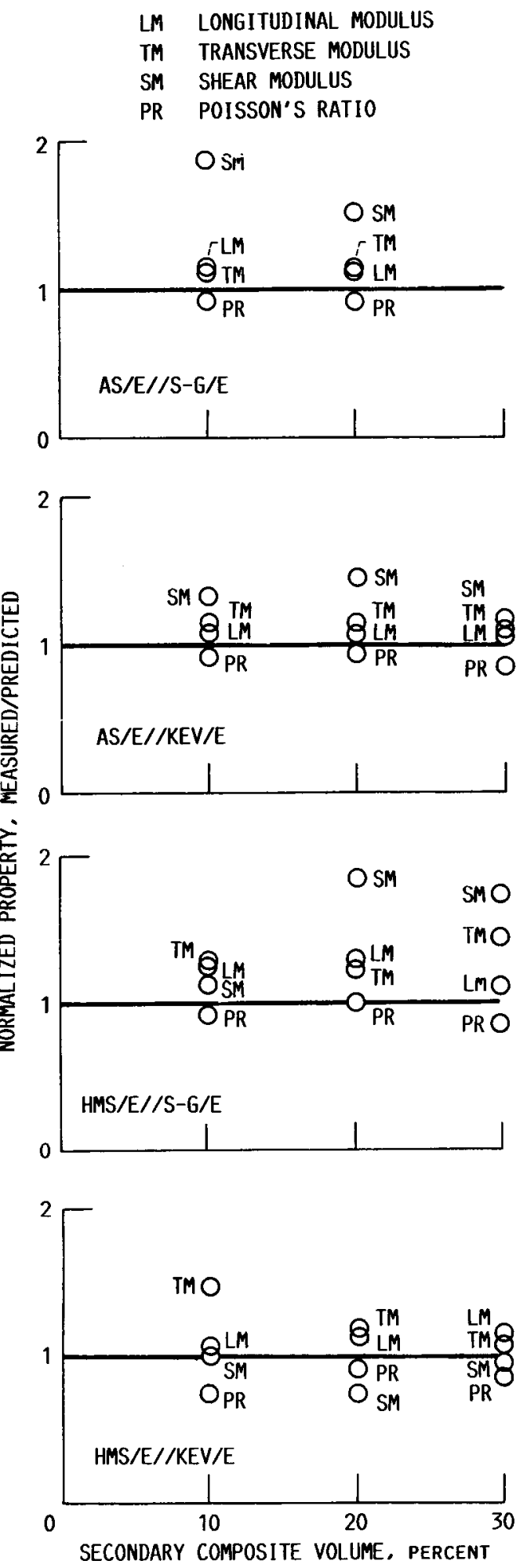

FIGURE 6. - ELASTIC PROPERTY TRANSLATION EFFICIENCY SUMMARY OF INTRAPLY HYBRIDS. 
1. LONGitudinal tension: $S_{\ell l i T} \approx k_{f} S_{f T}$

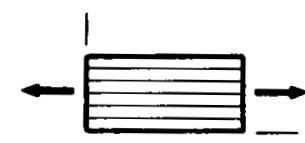

2. LONGITUDINAL COMPRESSION:

$\begin{array}{ll}\text { FIBER COMPRESSION: } & \mathrm{S}_{\ell 11 \mathrm{C}} \approx \mathrm{k}_{\mathrm{f}} \mathrm{S}_{\mathrm{fC}} \\ \text { DELAMINATION/SHEAR: } & \mathrm{S}_{\ell 11 \mathrm{C}} \approx 10 \mathrm{~S}_{\ell 12 \mathrm{~S}}+2.5 \mathrm{~S}_{\mathrm{mT}} \\ \text { MICROBUCKLING: } & \mathrm{S}_{\ell 11 \mathrm{C}} \approx \frac{\mathrm{G}_{\mathrm{m}}}{1-\mathrm{k}_{\mathrm{f}}\left(1-\frac{\mathrm{G}_{\mathrm{m}}}{\mathrm{G}_{\mathrm{fl}}}\right)}\end{array}$

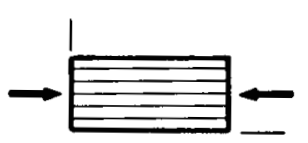

3. TRANSVERSE TENSION:

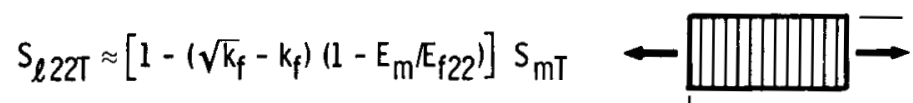

4. TRANSVERSE COMPRESSION:

$S_{\ell 22 C} \approx\left[1-\left(\sqrt{k_{f}}-k_{f}\right)\left(1-E_{m} / E_{f 22}\right)\right] S_{m C} \rightarrow\|n\| m \mid m-$

5. INTRALAMINAR SHEAR:

$S_{\ell 12 S} \approx\left[l-\left(\sqrt{k_{f}}-k_{f}\right)\left(1-G_{m} / G_{f 12}\right)\right] S_{m S}$

6. FOR VOIDS:

$$
\mathrm{S}_{\mathrm{m}} \approx\left\{1-\left[4 \mathrm{k}_{\mathrm{v}} /\left(1-\mathrm{k}_{\mathrm{f}}\right) \pi\right]^{1 / 2}\right\} \mathrm{S}_{\mathrm{m}}
$$

VOID $-\left[\begin{array}{llll}0 & 0 \\ 0 & 0 & 0 & 0 \\ 0 & 0 & 0\end{array}\right]$

FIGURE 7. - COMPOSITE MICROMECHANICS, UNIAXIAL STRENGTHS - IN-PLANE.

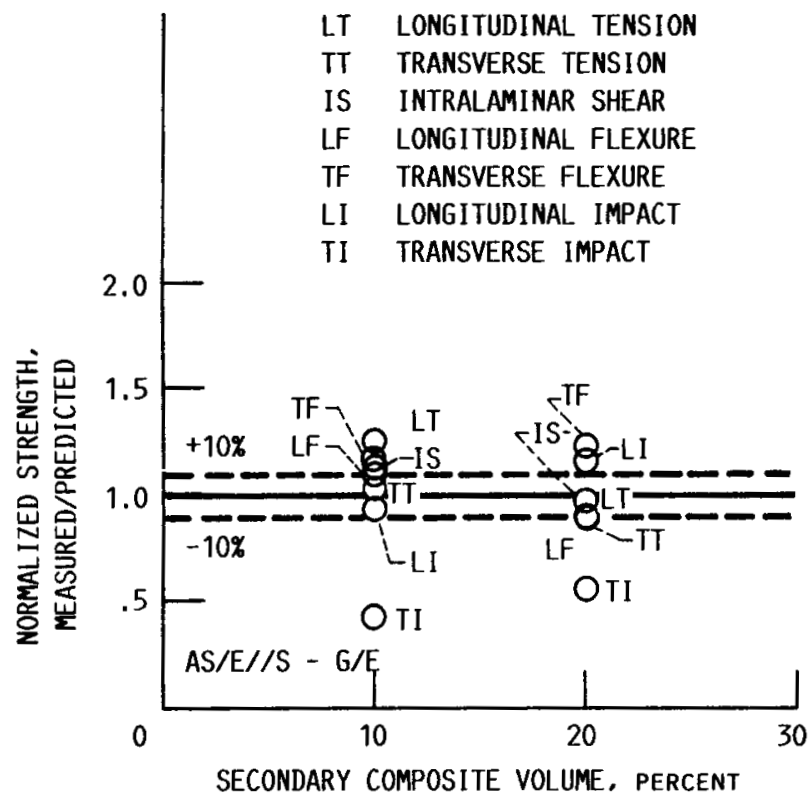

FIGURE 8. - STRENGTH TRANSLATION EFFICIENCY SUMMARY OF INTRAPLY HYBRIDS.

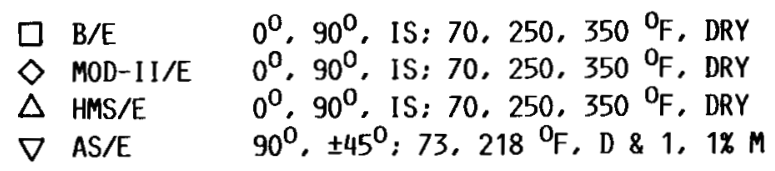

SOLID POINTS USED TO DETERMINE REFERENCE PROPERTIES

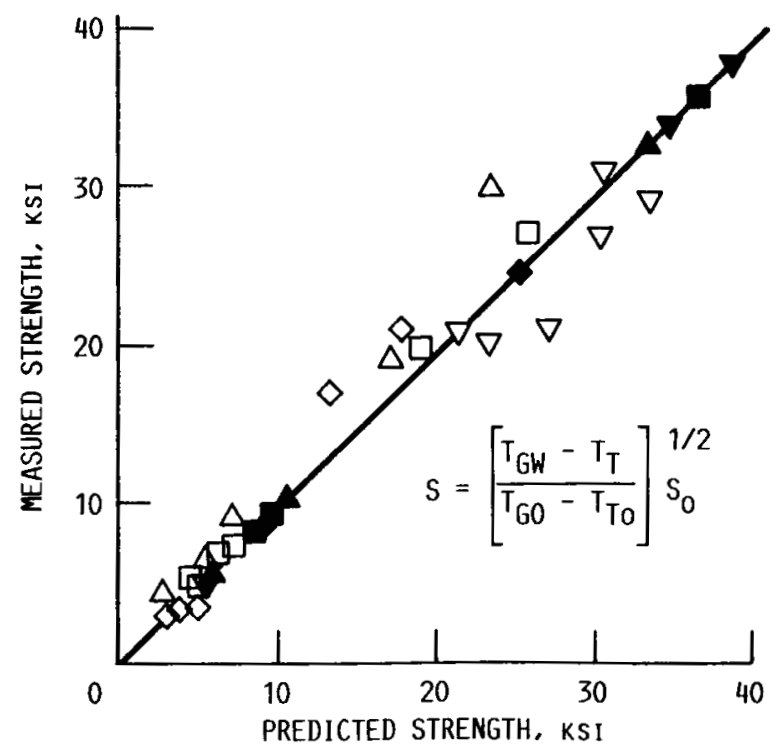

FIGURE 9. - HYGROTHERMAL EFFECTS ON STRENGTH PREDICTED ACCURATELY. 


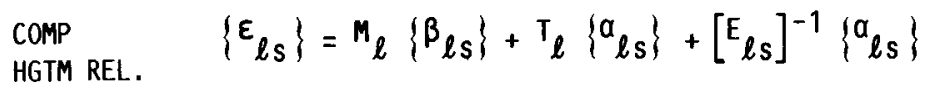

$$
\begin{aligned}
& \operatorname{PLY}_{\text {HGTM REL. }} \quad\left\{\varepsilon_{\ell m}\right\}=M_{\ell}\left\{\beta_{\ell m}\right\}+T_{\ell}\left\{\alpha_{\ell m}\right\}+\left[{ }_{\ell m}\right]^{-1}\left\{\alpha_{\ell m}\right\} \\
& \begin{array}{l}
\text { STRAIN } \\
\text { COMPAT. }
\end{array} \quad\left\{\varepsilon_{\ell m}\right\}=\left[{ }^{R_{\ell}}\right]\left\{\varepsilon_{\ell s}\right\} \\
& \begin{array}{l}
\text { STRESS } \quad\left\{\sigma_{\ell m}\right\}=\left[R_{\ell}^{\prime}\right]\left\{\sigma_{\ell s}\right\} \\
\text { EQUIL. }
\end{array} \\
& {\left[{ }^{R}\right]=\left\{\varepsilon_{\ell s}\right\}=M_{\ell}\left\{\beta_{\ell m}\right\}+T_{\ell}\left\{\alpha_{\ell m}\right\}+\left[{ }_{\ell m}\right]^{-1}\left[R_{\ell}^{\prime}\right]\left\{\sigma_{\ell s}\right\}} \\
& \left\{\varepsilon_{\ell s}\right\}=\left[R_{\ell}^{\prime}\right]^{-1}<{ }^{M} \ell\left\{\beta_{\ell m}\right\}+{ }^{T} \ell\left\{{ }^{\alpha} \ell m\right\}+\left[{ }_{\ell m}\right]^{-1}\left[{ }^{R_{\ell}^{\prime}}\right]\left\{\sigma_{\ell s}\right\}>
\end{aligned}
$$

COMPARING COEFFICIENTS IN FIRST AND LAST EQUATIONS:

$$
\left\{\beta_{\ell s}\right\}=\left[R_{\ell}\right]^{-1}\left\{\beta_{\ell m}\right\} ;\left\{\alpha_{\ell s}\right\}=\left[R_{\ell}\right]^{-1}\left\{\alpha_{\ell m}\right\} ;\left[{ }_{\ell m}\right]^{-1}=\left[{ }^{R_{l}}\right]^{-1}\left[E_{\ell m}\right]\left[R_{l}^{\prime}\right]
$$

FIGURE 10. - TRANSFORMATION OF HYGRAL (MOISTURE) PROPERTIES.

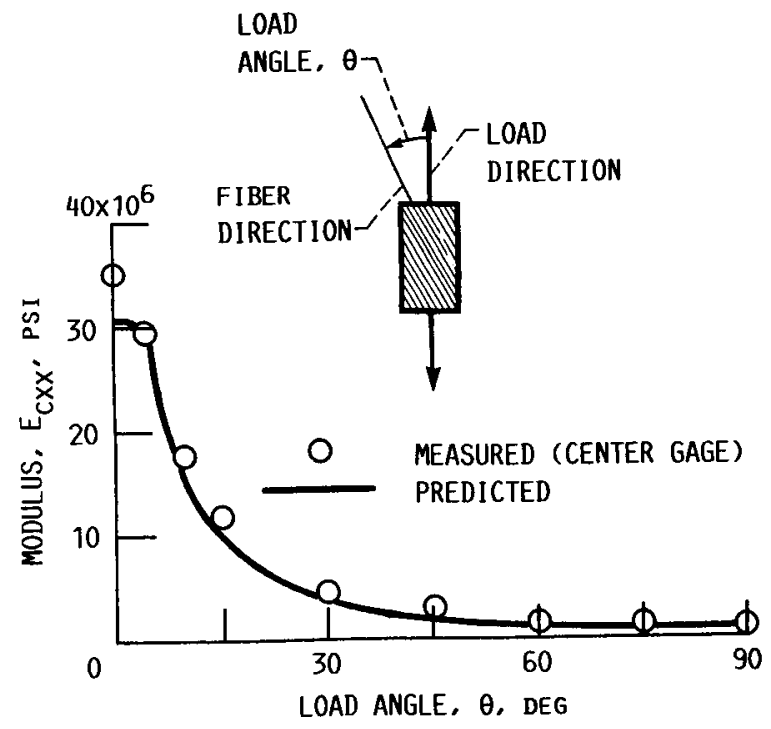

FIGURE 11. - MODULUS COMPARISONS.

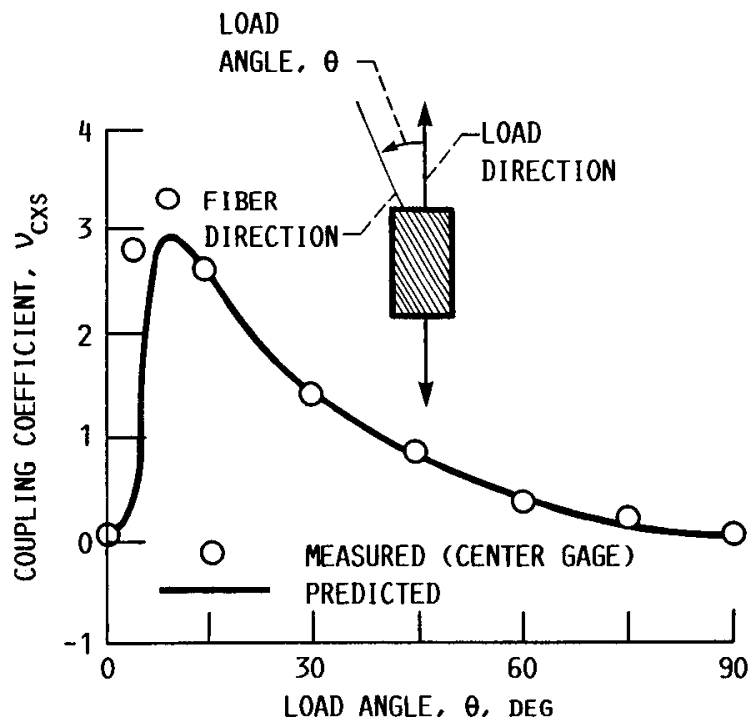

FIGURE 12. - COUPLING COEFFICIENT COMPARISONS. 


$$
\begin{aligned}
& F\left(\sigma_{\ell}, s_{\ell} \cdot E_{\ell}, \tilde{F}_{H T M}\right)=1-\frac{\sigma_{c x x} E_{\ell 11^{2}}}{E_{C X X}^{2}}\left\{\frac{1}{s^{2}}\left[\left(1-v_{\ell 21 \alpha} v_{c x y}\right) \cos ^{2} \theta+\left(v_{\ell 21}-v_{c x y}\right) \sin ^{2} \theta\right] 2\right. \\
& +\frac{\mathscr{T}^{2} \mathrm{E}_{\ell 22}^{2}}{\mathscr{F}_{\mathrm{HTM}}^{2} \mathrm{E}_{\ell 11}^{2} s_{\ell 22 \beta}^{2}}\left[\left(v_{\ell 12}-v_{\mathrm{cxy}}\right) \cos ^{2} \theta+\left(1-v_{\mathrm{Cx} y} v_{\ell 21}\right) \sin ^{2} \theta\right]_{\beta}^{2}
\end{aligned}
$$

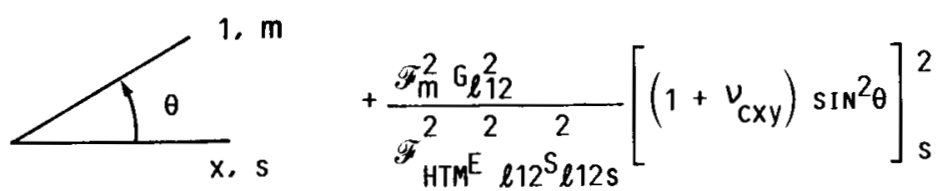

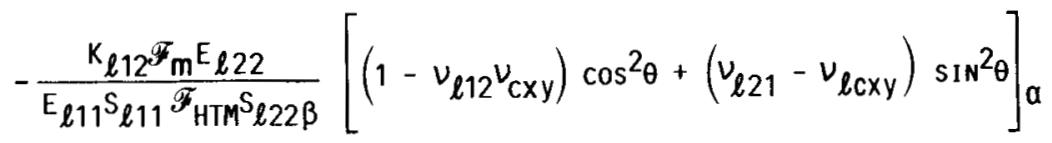

$$
\begin{aligned}
& \left.x\left(v_{\ell 12}-v_{c x y}\right) \cos ^{2} \theta+\left(1-v_{c x y} v_{\ell 21}\right) \sin ^{2} \theta\right]_{\beta}
\end{aligned}
$$

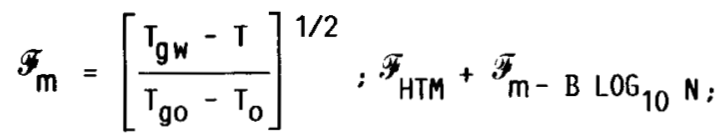

$\alpha, \beta=$ TENSION OR COMPRESSION

FIGURE 13. - PLY COMBINED STRESS FAILURE CRITERION WITH HYGROTHERMOMECHANICAL EFFECTS.

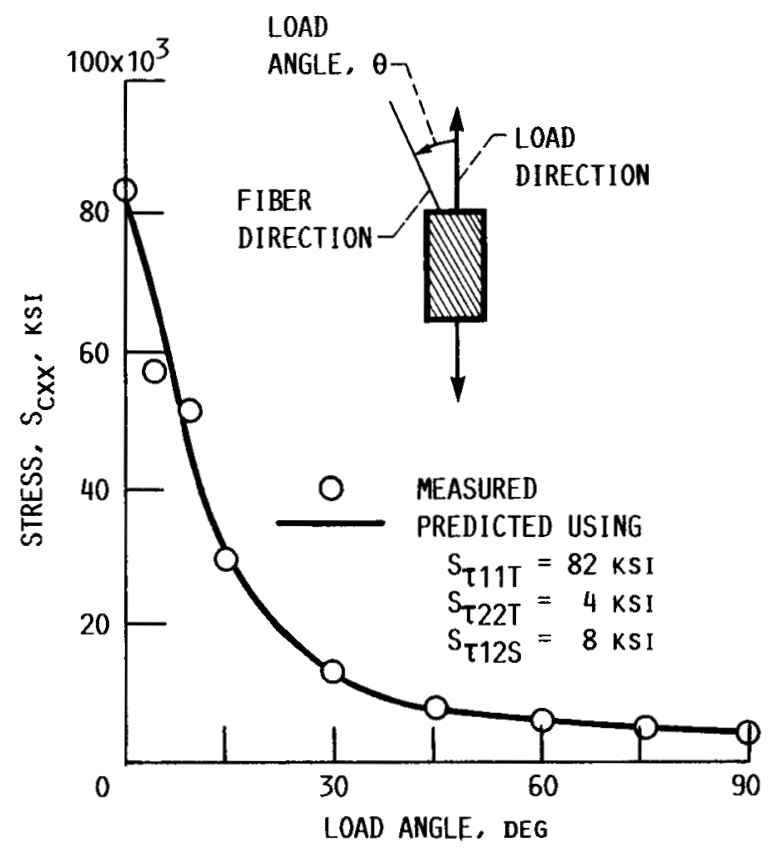

FIGURE 14. - FRACTURE STRESS (STRENGTH) COMPARISONS. 


$$
\begin{aligned}
& \operatorname{HGTM}_{\text {RELAT. }}^{\text {his }}\left\{:\left\{\varepsilon_{\ell}\right\}=\left[{ }^{E_{\ell}}\right]^{-1}\left\{\sigma_{\ell}\right\}+\Delta \mathrm{T}_{\ell}\left\{\alpha_{\ell}\right\}+m_{\ell}\left\{\beta_{\ell}\right\}\right.
\end{aligned}
$$

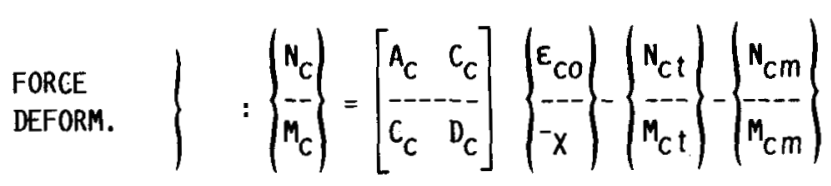

$$
\begin{aligned}
& \underset{\text { StRAIN }}{\text { PLY }}\}:\left\{\varepsilon_{\ell}\right\}=\left[{ }_{\ell \varepsilon}\right]<\left\{\varepsilon_{c o}\right\}-z_{\ell}\left\{X_{c}\right\}> \\
& \begin{array}{l|}
\text { PLY } \\
\text { STRESS }
\end{array} \quad:\left\{\varepsilon_{\ell}\right\}=\left[E_{\ell}\right]<\left[{ }^{R} \ell \varepsilon\right]\left\{\varepsilon_{\ell}\right\}-m_{\ell}\left\{\beta_{\ell}\right\}-\Delta T\left\{a_{\ell}\right\}> \\
& \left.\begin{array}{l}
\underset{\text { LAMINATE }}{\text { STRUCTURAL }} \\
\text { RESPONSE }
\end{array}\right\}:\left[A_{\mathrm{C}}, C_{\mathrm{C}}, \mathrm{D}_{\mathrm{C}}\right]=\sum_{\mathrm{L}=1}^{\mathrm{N}}<\left(\mathrm{Z}_{\mathrm{T}}-\mathrm{Z}_{\mathrm{B}}\right), \frac{1}{2}\left(\mathrm{Z}_{\mathrm{T}}^{2}-\mathrm{Z}_{\mathrm{B}}^{2}\right) \text {, } \\
& \frac{1}{3}\left(z_{T}^{3}-z_{B}^{3}\right)\left[R_{\ell}\right]^{T}\left[E_{\ell}\right]\left[R_{\ell}\right]>_{i}
\end{aligned}
$$

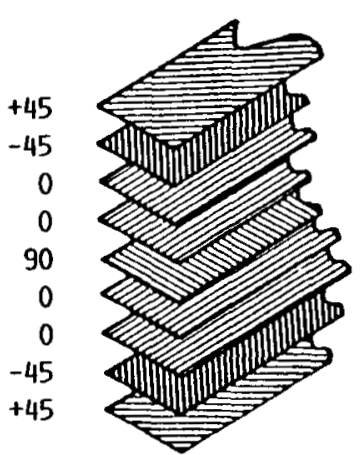

FiguRE 15. - LAMINATE THEORY EQUATIONS FOR hYGROTHERMOMECHANICAL (HGTM) LAMINATE. 


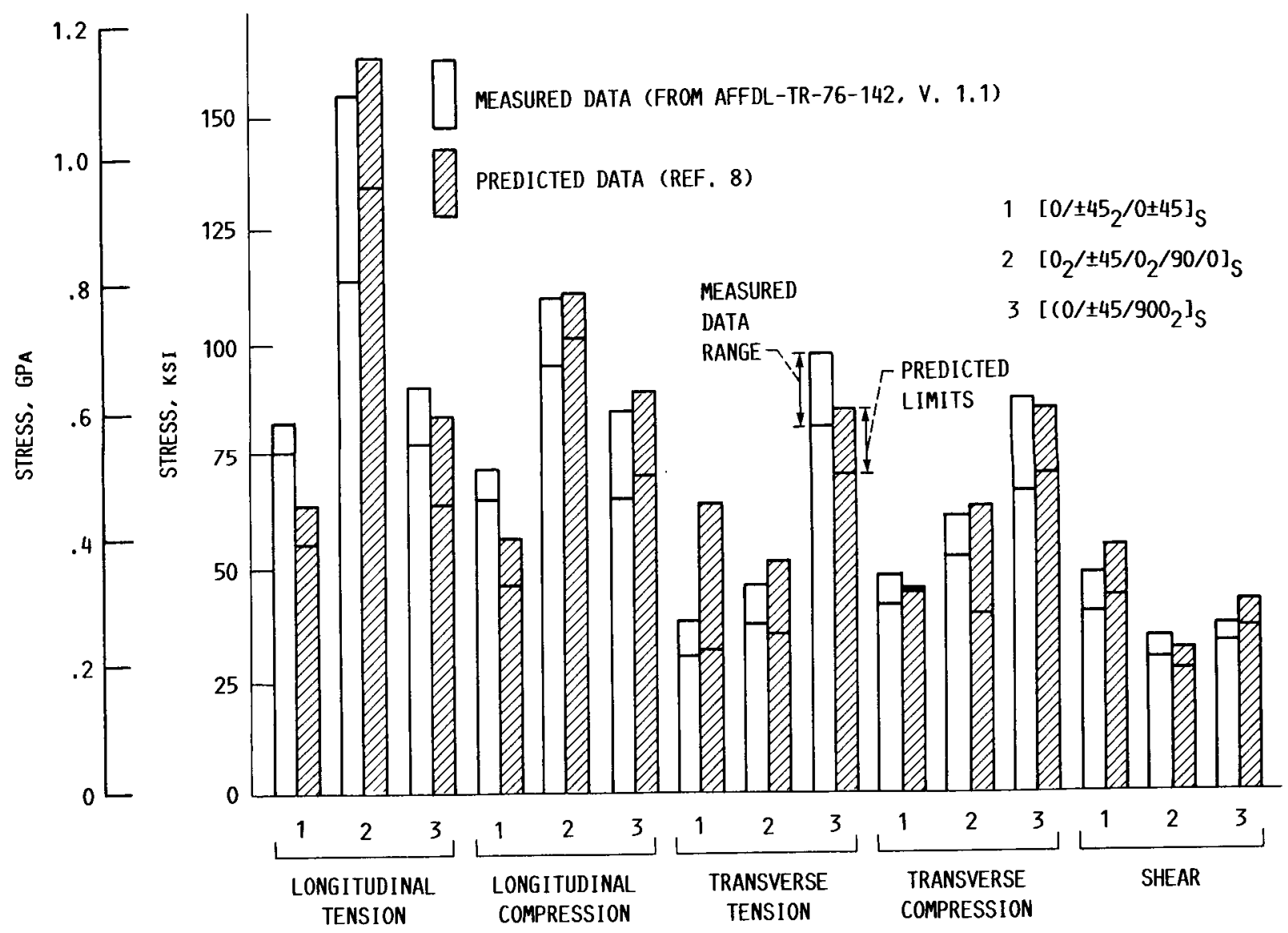

FIGURE 16. - FRACTURE STRESS OF WET COMPOSITES IS ACCURATELY PREDICTED BY LERC INTEGRATED THEORY FOR HYDROTHERMOMECHANICAL RESPONSE. 


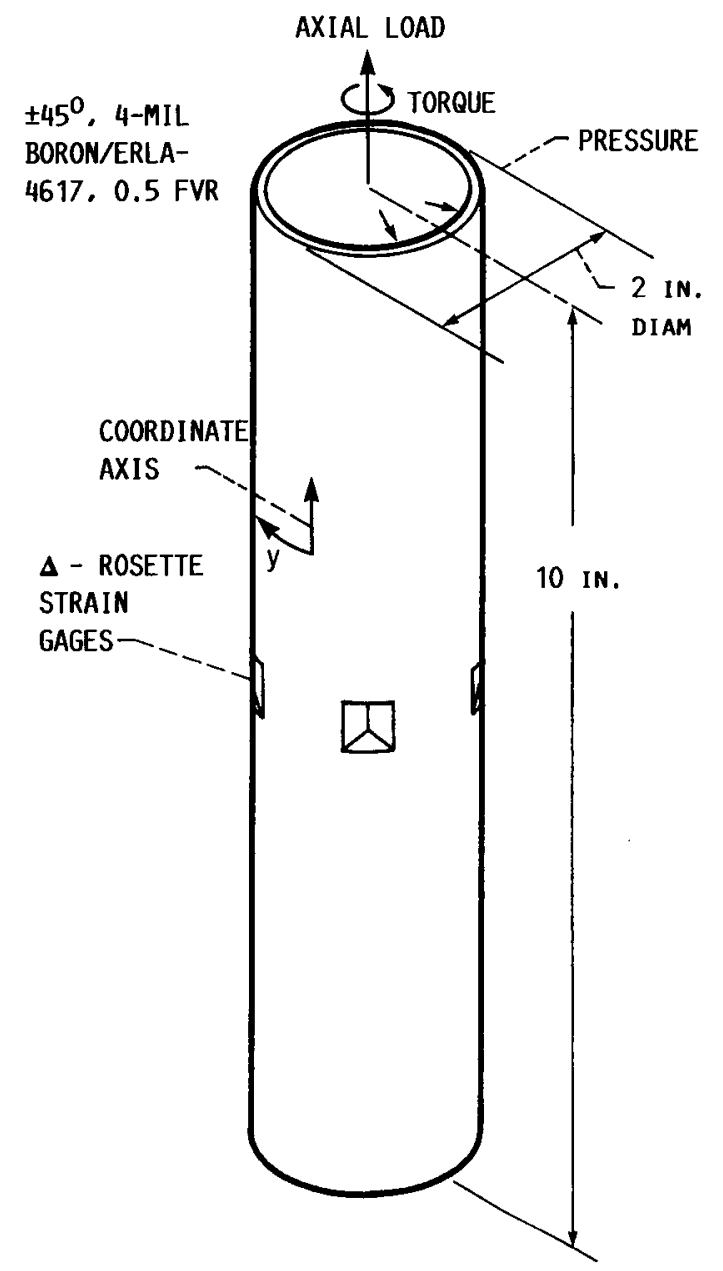

FIGURE 17. - SCHEMATIC OF COMPOSITE TUBE SPECIMEN SHOWING LOADS AND INSTRUMENTATION. 


$$
\begin{aligned}
& \frac{\sigma_{C \theta \theta}}{\sigma_{C X X}}=\frac{E_{C \theta \theta}}{E_{C X X}}\left\{R_{0}\left[\left(R_{0}+R_{D I}\right) \sin ^{2} \varphi\right] \cos ^{2} \theta\right. \\
& +\left[\left(1+R_{D \mid}\right) \cos ^{2} \varphi\right] \sin ^{2} \theta \\
& \left.-\frac{R_{D I}}{4}\left(1+R_{0}+R_{D I}\right) \sin 2 \varphi \sin 2 \theta\right\} \\
& R_{0}=\sqrt{E_{c x x} E_{c y y}} \\
& R_{D 1}=\left[2\left(\frac{E_{c x x}}{E_{c y y}}-u_{c x y}\right)+\frac{E_{c x x}}{G_{c x y}}\right]^{1 / 2} \\
& \frac{\sigma_{C \theta \theta}}{\sigma_{C X Y}}=\frac{E_{C \theta \theta}}{2 E_{C X X}}\left(1+R_{0}+R_{D I}\right)\left\{-R_{D I} \cos 2 \varphi \sin 2 \theta\right. \\
& \left.+\left\{\left(1+R_{0}\right) \cos 2 \theta+R_{0}-1\right] \sin 2 \varphi\right\}
\end{aligned}
$$

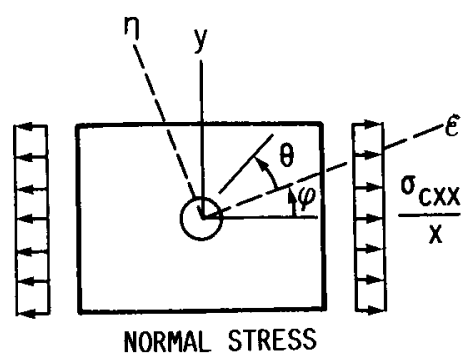

NORMAL STRESS

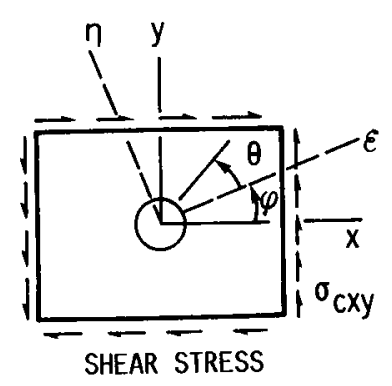

FIGURE 18. - STRESS CONCENTRATIONS DEPEND SIGNIFICANTLY ON COMPOSITE MODULI.

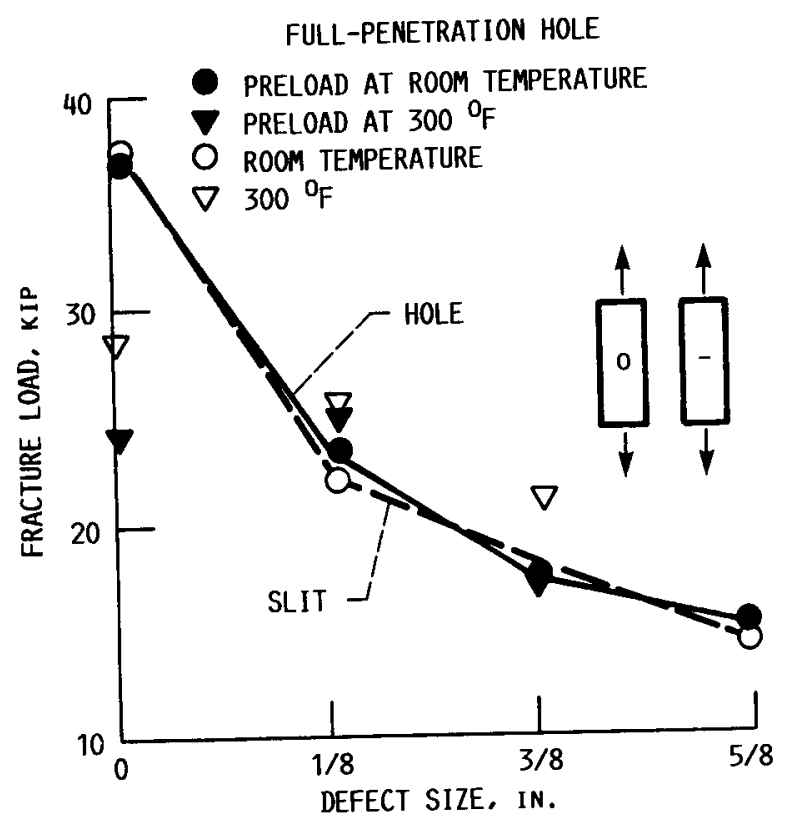

FIGURE 19. - DEFECTED LAMINATE STATIC

FRACTURE DATA. 

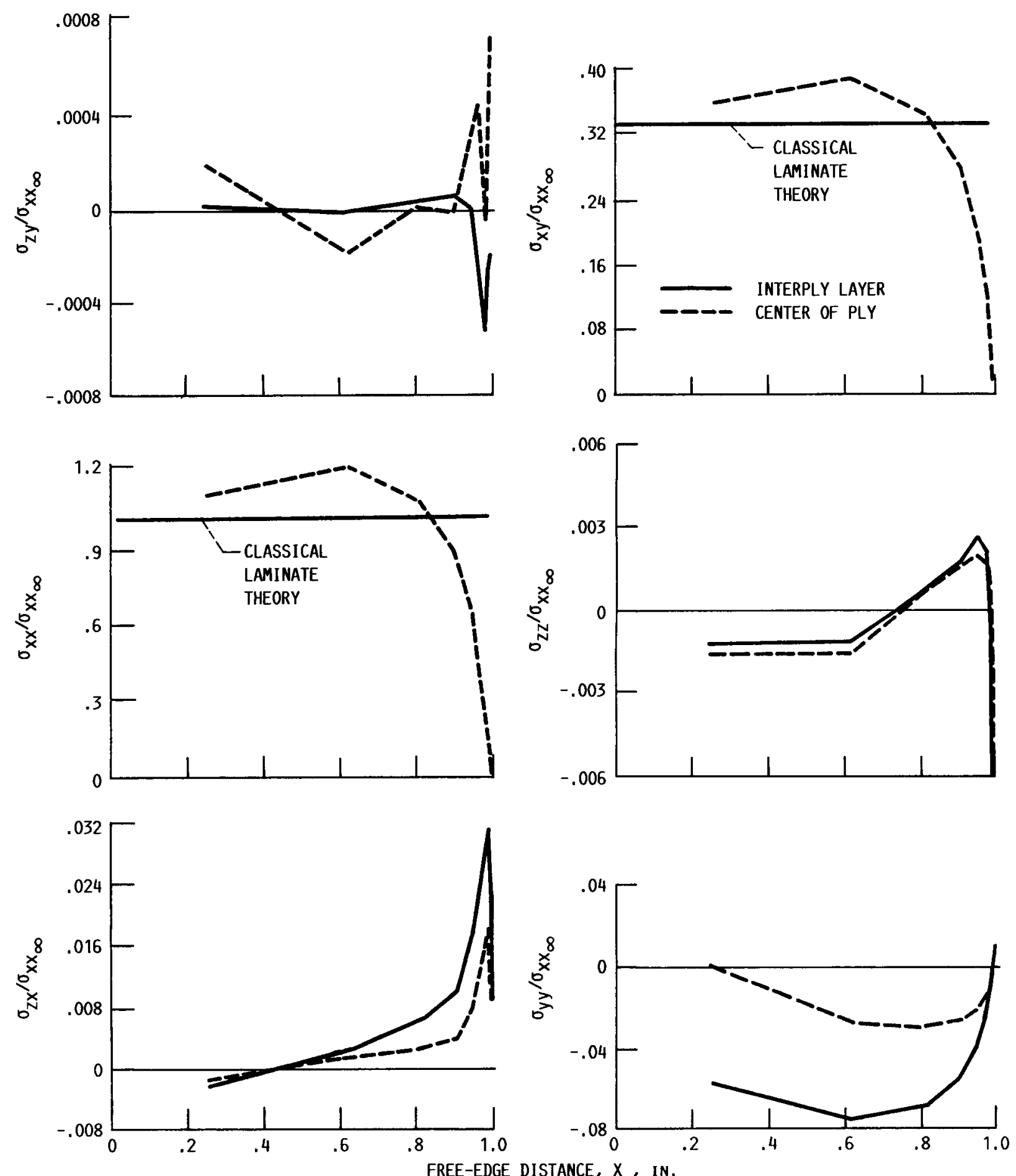

FIGURE 20. - 3-D PLY AND INTERPLY STRESS FIELDS AS THE FREE EDGE IS APPROACHED $\left(+20^{\circ} \mathrm{PLY},[ \pm 20]\right.$ AS/E LAMINATE). 


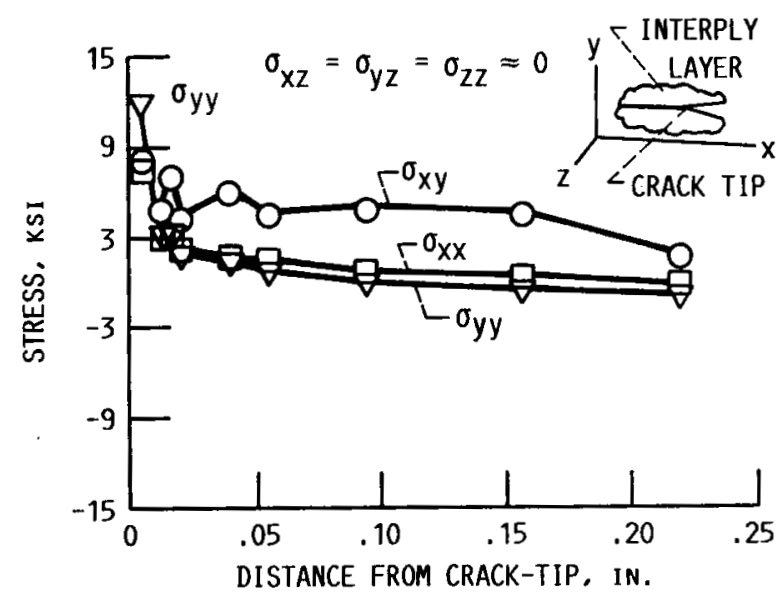

FIGURE 21. - STRESS FIELD IN INTERPLY LAYER NEAR CRACK TIP.

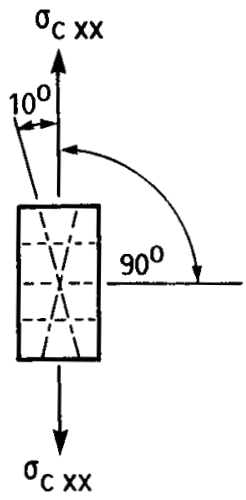

LAMINATE

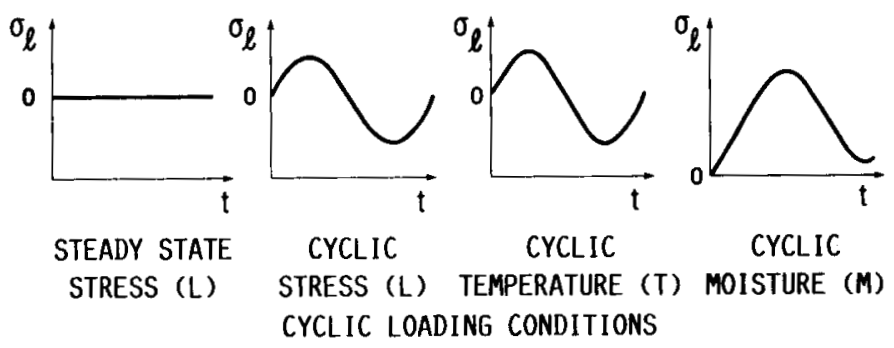

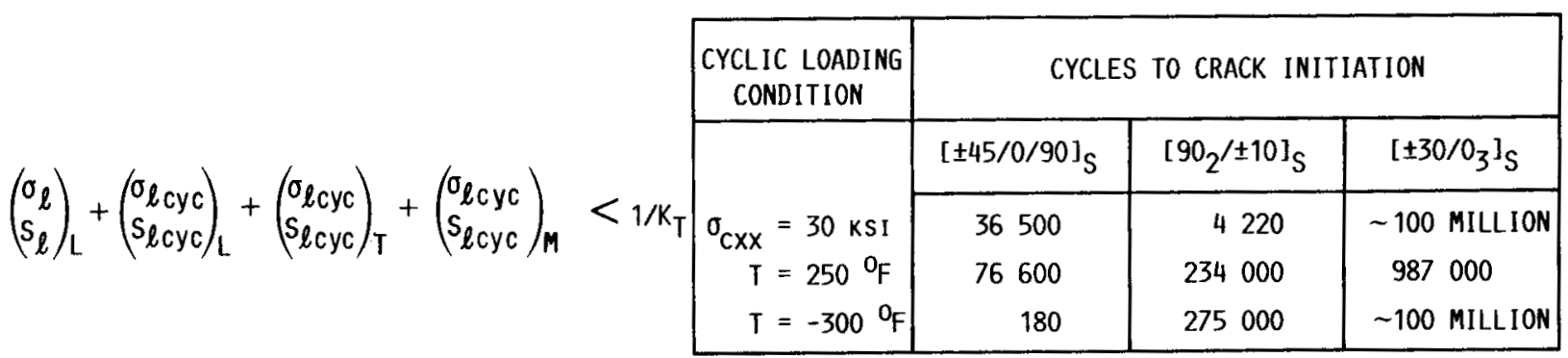

FIgURE 22. - COMPUTATINAL SIMULATION OF HYGROTHERMOMECHANICAL FATIGUE IN FIBER COMPOSITES. 


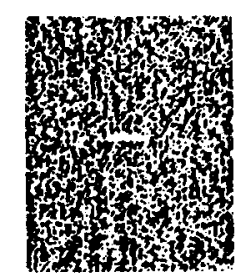

(a) NO LOAD.

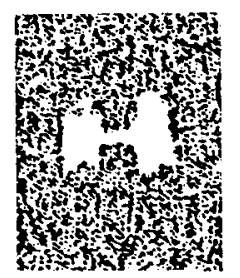

(b) LOAD EQUAL APPROXIMATELY ONE-HALF FRACTURE LOAD.

C-SCAN RECORD

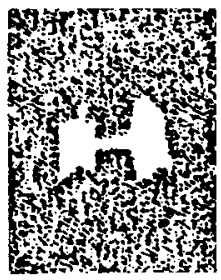

C-SCAN RECORD

INTERCHANGE

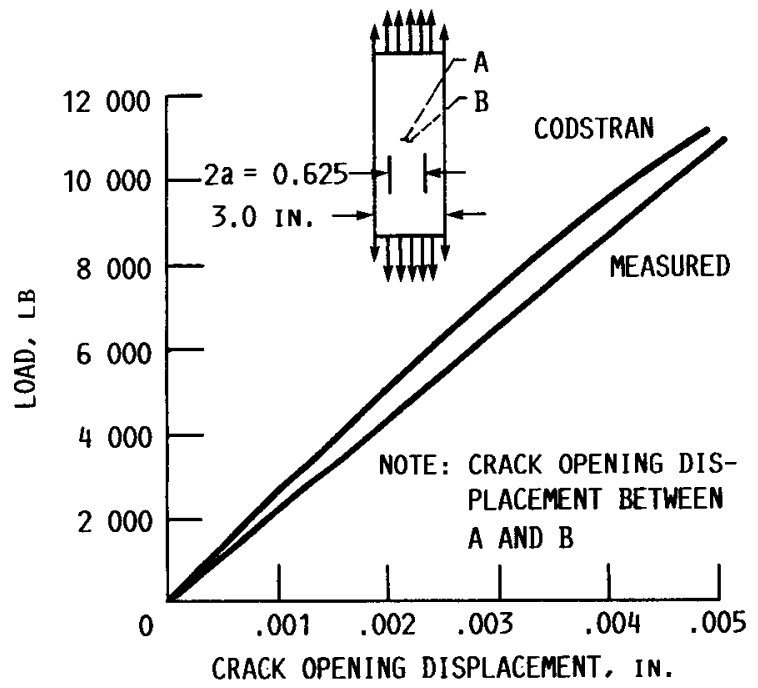

FIGURE 23. - CODSTRAN PREDICTED RESULTS COMPARED WITH EXP DATA.

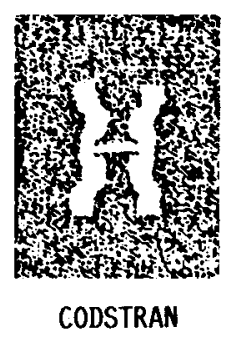

CODSTRAN
- DETERMINE REQUISITE PROPERITIES AT DESIRED CONDITIONS USING COMPOSITE MICROMECHANICS

- RUN 3-D FINITE ANALYSIS ON ENF (MMF) FOR AN ARBITRARY LOAD

- SCALE LOAD TO MATCH INTERLAMINAR SHEAR STRESS AT ELEMENT NEXT TO CRACK-TIP

- With SCALED LOAD EXTEND CRACK AND PLOT STRAIN ENERGY RELEASE (G) VERSUS CRACK LENGTH (a)

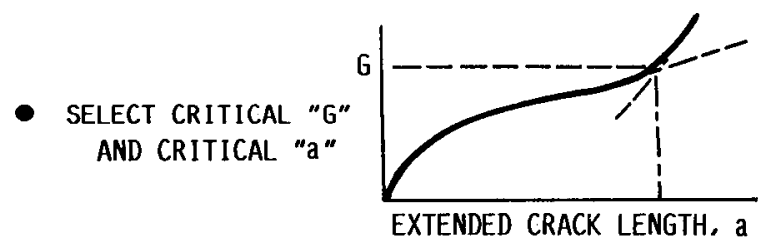

- METHOD HAS VERSATILITY/GENERALITY

FIGURE 24. - GENERAL PROCEDURE FOR PREDICTING COMPOSITE INTERLAMINAR FRACTURE TOUGHNESS USING THE END-NOTCH-FLEXURE (ENF) OR MIXEDMODE-FLEXURE (MMF) METHOD. 


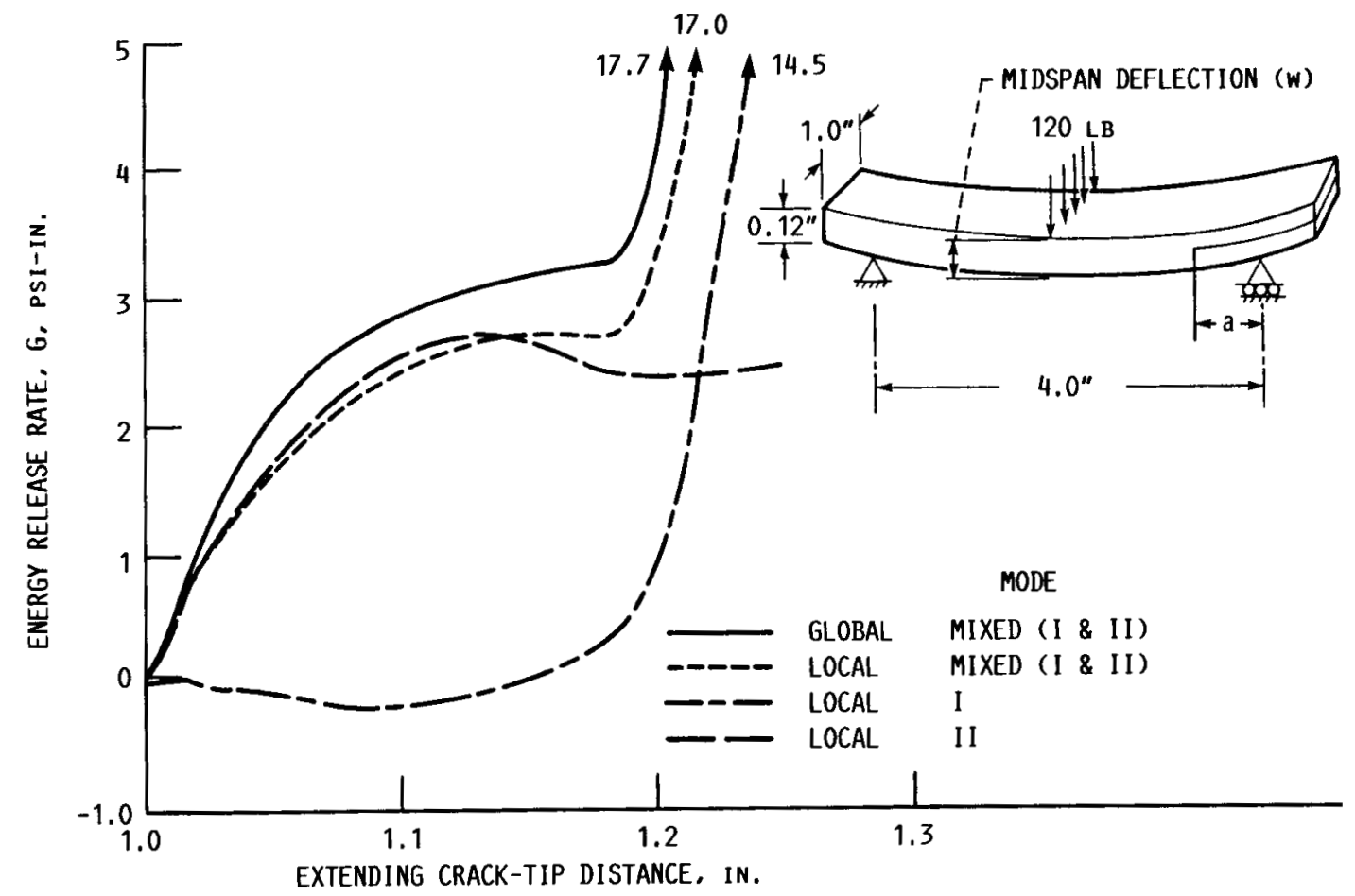

FIGURE 25. - MIXED-MODE-FLEXURE ENERGY RELEASE RATE AND COMPONENTS (AS/E). 


$$
\begin{aligned}
& {[M]\{i u\}+[C] \quad\{\dot{u}\}+[K]\{u\}=\{F(t)\}} \\
& \{\omega\} \leq\{\omega a\} \\
& \left\langle[K]-\omega^{2}[M]\right\rangle\{u\}=0 \rightarrow\{\omega\} \\
& \{u\} \leq\left\{u_{a}\right\} \\
& \{\sigma\}=[E]^{-1}[L(G)]\{u\} \leq\left\{S_{a}\right\} \\
& \leq\left\{S_{C r}\right\} \\
& \langle[K]-[I]\rangle\{u\}=\{0\} \rightarrow\left\{S_{C r}\right\}
\end{aligned}
$$

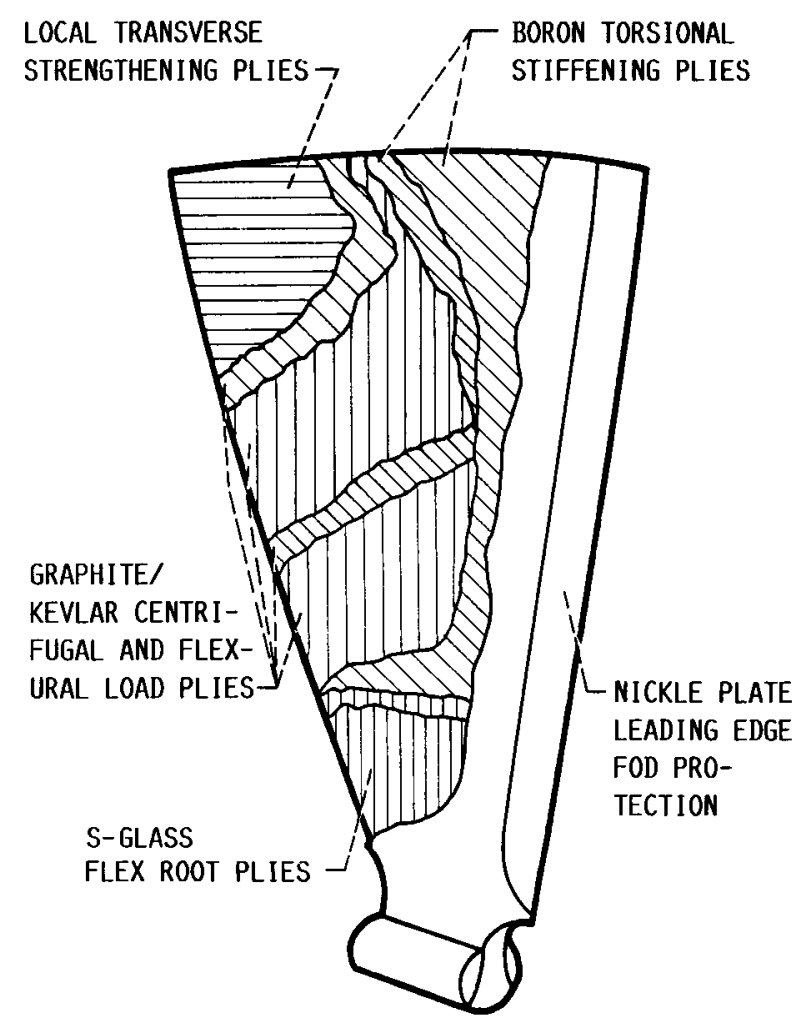

FIGURE 26. - STRUCTURAL BEHAVIOR/RESPONSE GOVERNING EQUATIONS.

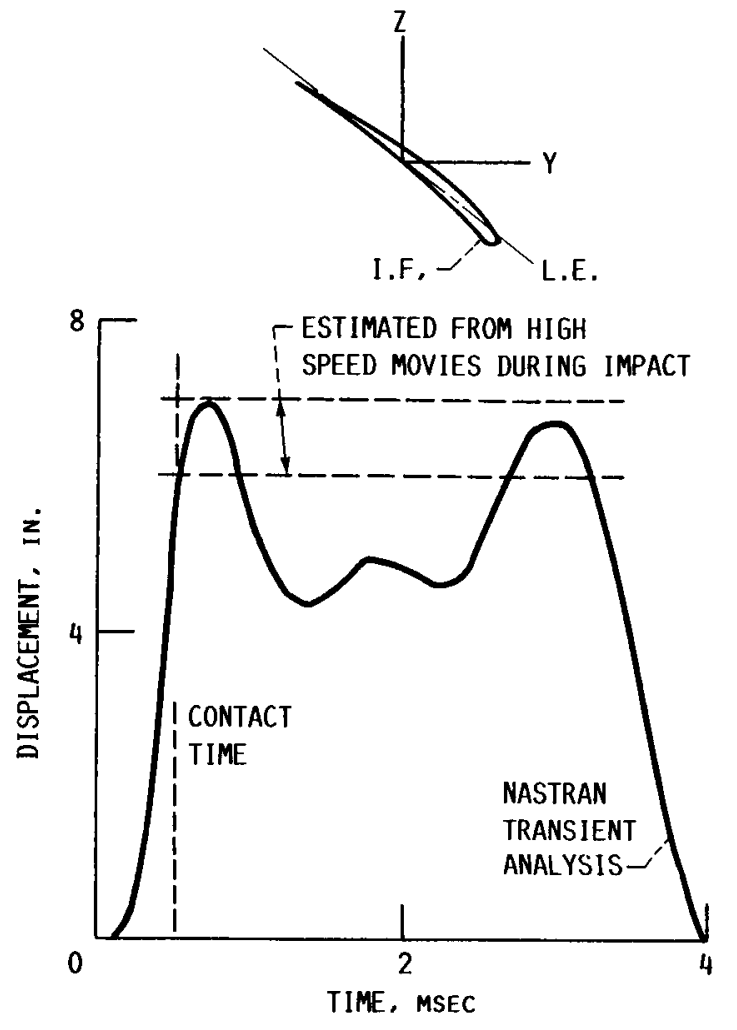

FIGURE 27. - Z-COMPONENT OF L.E. TIP DISPLACEMENT. HYBRID COMPOSITE FAN BLADE, 2-LB BIRD IMPACT. 


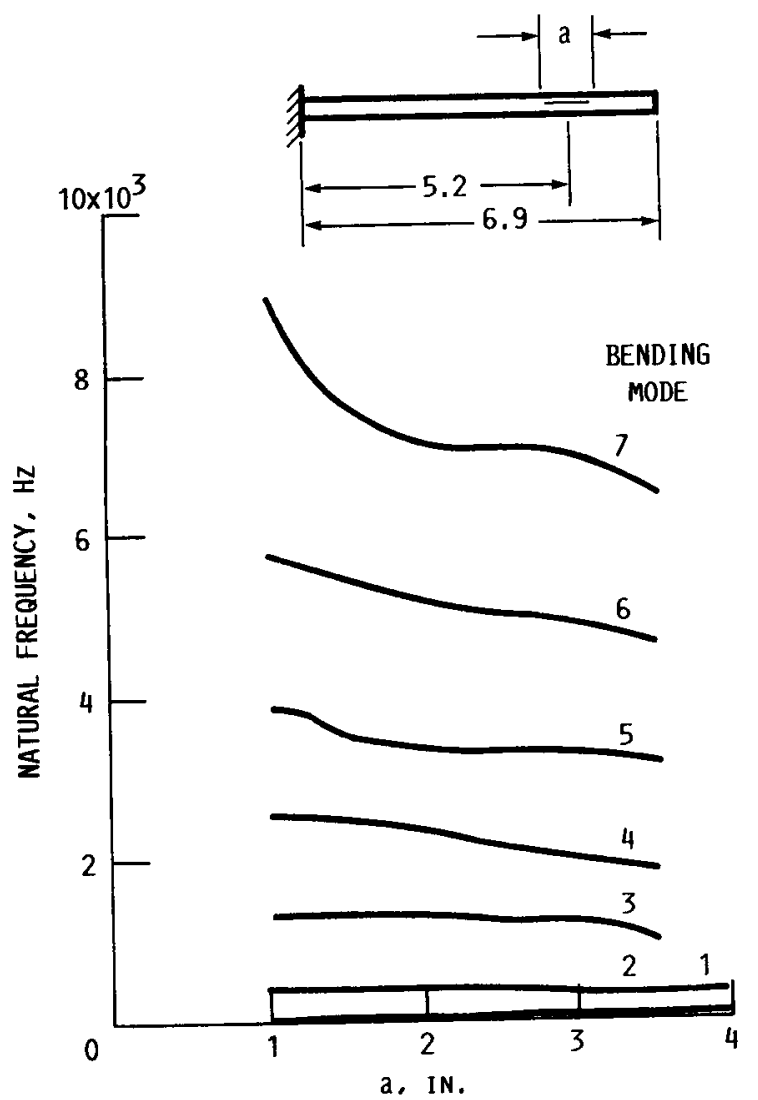

FIGURE 28. - EFFECT OF CRACK LENGTH ON LOWEST NATURAL FREQUENCIES. 


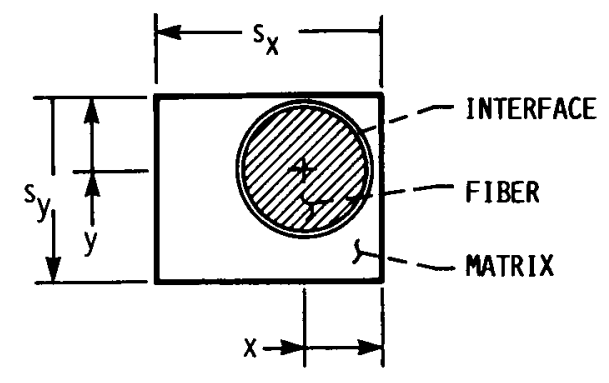

$s_{x}, s_{y}, x, y, d_{f}, d_{i}$ RECTANGULAR ARRAY (6)

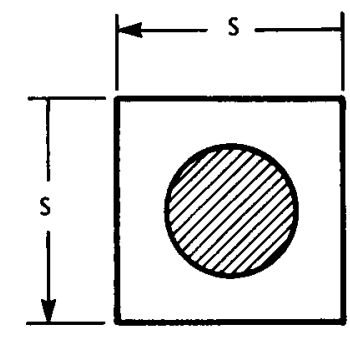

s, $d_{f}$ SQUARE ARRAY (2)

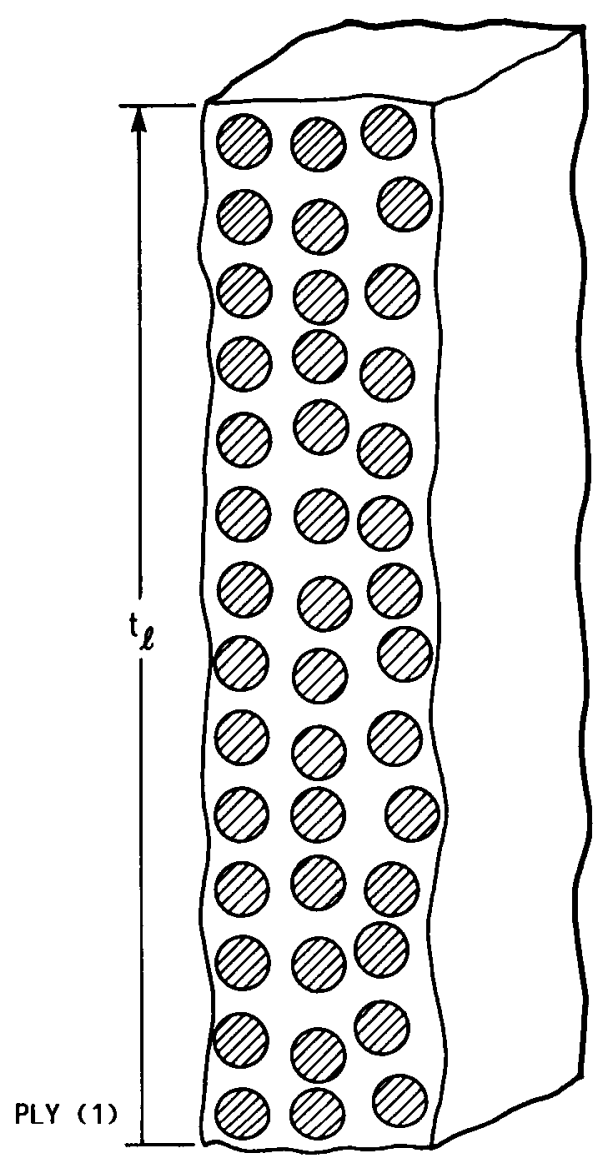

FIGURE 29. - COMPOSITE MICROMECHANICS - SCALE LEVELS. 


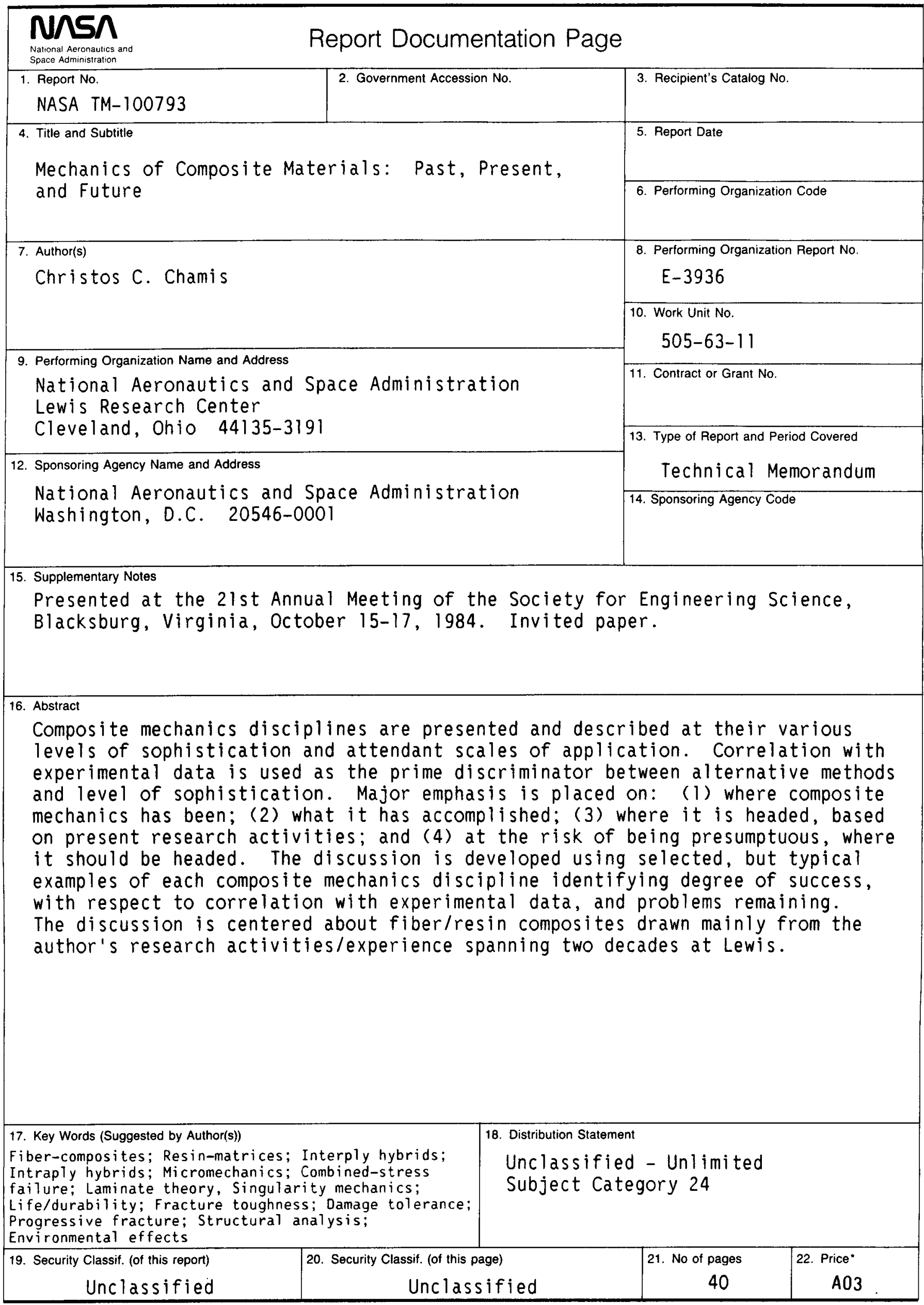

